\title{
Long-term changes in abundances of Sonoran Desert lizards reveal complex responses to climatic variation
}

Running head: Climatic variation and lizard populations

\author{
AARON D. FLESCH ${ }^{1}$, PHILIP C. ROSEN ${ }^{2}$, PETER HOLM ${ }^{3}$ \\ ${ }^{1}$ School of Natural Resources and the Environment, University of Arizona, The Desert \\ Laboratory, 1675 Anklam Road, Tucson, AZ, 85745, USA \\ ${ }^{2}$ School of Natural Resources and the Environment, University of Arizona, 325 Biosciences East, \\ Tucson, AZ, 85721, USA \\ ${ }^{3}$ National Park Service, Organ Pipe Cactus National Monument, 10 Organ Pipe Drive, Ajo AZ \\ 85321, USA
}

*Correspondence: Aaron D. Flesch, tel+520 621 7255, fax +520 621 8801, email:

flesch@email.arizona.edu

Keywords: aridlands, climate change, ectotherms, $N$-mixture models, population trends, precipitation, Sonoran Desert, temperature.

Type of Paper: Original Research - Primary Research Article 


\begin{abstract}
:
Understanding how climatic variation affects animal populations and communities is essential for addressing threats posed by climate change, especially in systems where impacts are projected to be high. We evaluated abundance dynamics of five common species of diurnal lizards over 25 years in a Sonoran Desert transition zone where precipitation decreased and temperature increased across time, and assessed hypotheses for the influence of climatic flux on spatiotemporal variation in abundances. We repeatedly surveyed lizards in spring and summer of each year at up to 32 sites, and used hierarchical mixture models to estimate detection probabilities, abundances, and population growth rates. Among terrestrial species, abundances of a short-lived, winter-spring breeder increased markedly by an estimated $237-285 \%$ across time, while two larger spring-summer breeders with higher thermal preferences declined by up to $64 \%$. Abundances of two arboreal species that occupy shaded and thus sheltered microhabitats fluctuated but did not decline systematically. Abundances of all species increased with precipitation at short lag times (1-1.5 yrs) likely due to enhanced food availability, but often declined after periods of high precipitation at longer lag times (2-4 yrs) likely due to predation and other biotic pressures. Although rising maximum daily temperatures $\left(T_{\max }\right)$ are expected to drive global declines of lizards, associations with $T_{\max }$ were variable and weak for most species. Instead, abundances of all species declined with rising daily minimum temperatures, suggesting degradation of cool refugia imposed widespread metabolic or other costs. Our results suggest climate warming and drying are having major impacts on lizard communities by driving declines of species with traits that augment exposure to abiotic extremes and by modifying species interactions. The complexity of patterns we report indicate that evaluating and responding to the influence of climate change on biodiversity must consider a broad array of ecological processes.
\end{abstract}




\section{Introduction}

Understanding how climatic variation influences the dynamics of animal populations and communities is important for assessing threats posed by climate change and guiding conservation and adaptation strategies. In arid and semi-arid environments (aridlands), climate change could have particularly severe effects on communities by increasing the frequency of extreme events and because the velocity of climate change may be higher in these often resource-limited systems (Easterling et al., 2000; Kerr, 2008; Loarie et al., 2009; Smith, 2011). In aridlands, small changes in precipitation can have large and rapid effects on plant productivity and exert a complexity of direct and indirect effects on communities at varying trophic levels and lag times (Beatley 1969; Lima et al., 2002; Holmgren et al., 2006; Knapp et al., 2015). When coupled with biotic interactions such as competition and predation (Bellard et al., 2012; Blois et al., 2013), small changes in precipitation and temperature can have large effects on animal communities, which has broad implications given aridlands cover $>40 \%$ of land on Earth but have been the focus of few long-term studies.

In arid southwestern North America, recent evidence of climate change is pervasive and expected to intensify (Seager et al., 2007; Overpeck and Udall, 2010; Garfin et al., 2013, Cook et al. 2015). Such signs include extreme drought and temperature events that have dominated regional climates recently and been linked to marked declines in vital and population growth rates in the few vertebrate populations that have been monitored recently (Barrows, 2006; Moses et al., 2012; Zylstra et al., 2013; Flesch, 2014; Lovich et al., 2014; Flesch et al. 2015; CruzMcDonnell and Wolf 2015; Gedir et al., 2015). Although such patterns include both ectotherms and endotherms, climate flux could have particularly severe effects on ectotherms such as reptiles because they are active only within narrow sets of thermal conditions that vary with the physiology and behavior of individual species (Deutsch et al., 2008; Angilletta, 2009), and 
because ectotherms can incur large metabolic costs as the environment warms (Huey et al. 2009; Kearney et al. 2009). In sunny, open environments, diurnal lizards sustain preferred body temperatures by selecting sun, shade, and substrates of varying temperatures (Cowles and Bogert, 1944; Huey, 1982), which moderates but may not eliminate the effects of rising environmental temperatures (Huey et al., 2009; Sinervo et al., 2010). Such behaviors involve retreating to thermal refugia to avoid lethally high temperatures (Dunham, 1993; Sinervo et al., 2010; Sheldon et al. 2011) and to limit the costs of maintenance metabolism during periods of seasonal dormancy and nocturnal inactivity (Bennett, 1982; Huey, 1982; Dunham et al. 1989). Thus for lizards, rising temperatures linked to climate change could constrain foraging, growth, reproduction, and other critical life history processes in ways that reduce vital and population growth rates and increase extinction risks (Huey et al. 2009; Kearney et al. 2009; Sinervo et al. 2010; Kearney 2013; Levy et al. 2016). Evaluating these threats and understanding how they are influencing communities, however, requires long-term, multi-species datasets that are rarely available.

Despite the importance of understanding how climatic variation is influencing vertebrate communities, extracting accurate inferences from field data can be challenging, particularly for ectotherms. This is because local variation in weather can have large effects on both individual activity, and thus detection probability during sampling, and also critical life history processes, and thus spatiotemporal changes in true abundance (Cowles and Bogert, 1944; Dunham et al., 1989). Therefore, differentiating the effects of weather on activity and abundance should improve our understanding of spatiotemporal changes in population size and factors that influence these dynamics (Kéry et al., 2009). Although such challenges are not new, analytical tools that explicitly consider the detection process when estimating temporal changes in 
abundances of unmarked animal populations - the only practical approach for monitoring many populations_-have only recently been developed (Kéry et al., 2009; Dail and Madsen, 2011).

Here, we assess long-term abundance dynamics of five common species of diurnal lizards in the Sonoran Desert, where recent drought and extreme temperature events could be having pervasive effects. Lizards provide a useful focal system for assessing ecological responses to climatic variation because (1) they are relatively abundant and observable, (2) temperature influences activity in complex ways depending on the behavior and physiology of each species (Milstead, 1967; Huey et al., 1983; Vitt and Pianka, 1994), and (3) in aridlands, precipitation can have marked bottom-up (via food supply) and top-down (via predation) effects on populations (Rosenzweig, 1968; Anderson, 1994; Lima et al., 2002; Walther, 2010). Thus, climatic variation could influence species differently depending on their physiology, microhabitat (e.g., terrestrial vs. arboreal), or trophic position (Huey and Tewksbury, 2009; Kearney et al., 2009; Sinervo et al., 2010), which varied among the five species we considered. Our goals were to (1) evaluate temporal variation in abundances of multiple species of lizards and estimate any systematic longterm trends, (2) evaluate hypotheses for the influence of spatiotemporal variation in local weather on population dynamics, and (3) assess how interspecific differences in species' traits contributed to dynamics.

\section{Materials and Methods}

\section{Study system}

We studied lizards in Organ Pipe Cactus National Monument (OPCNM), which is in the central Sonoran Desert in southern Arizona, USA. Since the late 1980s, lizards have been the focus of an intensive monitoring effort that, to our knowledge, provides the longest spatially-replicated annual time-series data for a vertebrate community in arid southwestern North America. Because 
monitoring spanned prolonged warm-wet phases of the El Niño Southern Oscillation (ENSO; 1991-1995, 1997-1998), and recent extreme drought and temperature events, this system provides a useful opportunity to assess the effects of climatic variation on a vertebrate assemblage in arid southwestern North America.

OPCNM is a large $(133,882 \mathrm{ha})$ reserve situated in a broad transition zone where desert woodlands of the Arizona Upland subdivision of the Sonoran Desert shift to more xeromorphic shrub-dominated desertscrub of the Lower Colorado River Valley subdivision (Bowers, 1980; Brown, 1982; Fig. 1). This transition is driven by decreasing elevation and increasing aridity from east to west and provides a useful context for monitoring because changes in populations and communities may occur first and be focused in transition zones where some species approach the limits of their ecological tolerances and where biotic and abiotic factors drive variation in community structure and composition (Barrows et al. 2016). Vegetation in the Arizona Upland subdivision is dominated by short open woodlands and denser thornscrub-like associations of leguminous trees such as foothill paloverde (Parkinsonia microphylla), ironwood (Olneya tesota), and velvet mesquite (Prosopis velutina) mixed with cacti, shrubs, perennial grasses, and annuals forbs (Brown, 1982). Lower Colorado River desertscrub is dominated by more open associations of shrubs and sub-shrubs such as creosote bush (Larrea tridentata) and bursage (Ambrosia sp.), with trees largely restricted to riparian zones along dry streambeds. Riparian areas in both subdivisions are dominated by woodlands of mesquite, catclaw acacia (Senegalia greggii), and blue paloverde (P.florida). Vegetation cover and structural complexity are often greater on rocky slopes and in canyons and riparian zones, and decline from east to west (Bowers, 1980). Typical of the Sonoran Desert, annual precipitation is bimodal and includes a summer monsoon in July-Sept and winter storms that are of increased intensity during the warm phase of ENSO. 
We considered five species of lizards that are common in the Sonoran Desert. These focal species have varying life histories and differ broadly in microhabitat, phenology, and other traits (Pianka et al., 1979; Pianka, 1993; Appendix S1). The tiger whiptail (Aspidoscelis tigris) and zebra-tailed lizard (Callisaurus draconoides) are exclusively terrestrial but differ in foraging mode, whereas the smaller side-blotched lizard (Uta stansburiana) is mainly terrestrial but also occurs on arid slopes where it is saxicolous (Pianka 1966). The smaller ornate tree lizard (Urosaurus ornatus) and larger desert spiny lizard (Sceloporus magister) are mainly arboreal but the later species also exhibits terrestrial habits (Vitt et al., 1981; Pianka, 1986). Whereas all species primarily consume arthropods, adults of larger species will consume smaller individuals of small species. Additionally, all species are active during the warm season, but the sideblotched lizard and tree lizard are also active in winter. Breeding by the side-blotched lizard peaks in late winter and spring (Asplund and Lowe, 1964), whereas other species are springsummer breeders (Appendix S1). In more arid regions west of OPCNM, the side-blotched lizard comprises an increasing proportion of lizard communities, the tree lizard is largely absent except in gallery forest, and other species decrease in abundance (Vitt and Ohmart, 1978; Rosen, 2007).

\section{Design}

We sampled lizards by repeatedly surveying the same line transects across time. We placed transects across OPCNM to represent gradients in elevation, soils, vegetation, and hydrology (Fig. 1). In 1989, we established 19 transects, 100-300 $\mathrm{m}$ in length and increased effort to 26 transects in 1994, and 32 in 2001. Between 1989 and 2013, we surveyed transects during 1, or rarely $2(n=20)$ days each spring (5 April-23 June) and summer (12 July-13 October), but not all transects were surveyed each year. To ensure effort coincided with periods of peak aboveground activity of each species, we surveyed during warm calm conditions. During each daily 
visit, we repeatedly surveyed transects 3-8 times beginning as early as 38 min after local sunrise and continuing as late as $6.8 \mathrm{hrs}$ after sunrise.

To survey lizards, one observer slowly walked transects and recorded the time, species, and when known, age class (juvenile, sub-adult, adult) of each individual observed from the center line. Transects were initially walked in directions away from the rising sun to augment visibility and only individuals observed within $7.5 \mathrm{~m}$ of transects were recorded because initial efforts indicated that most detections were within this distance. We recorded the time and used standard mercury thermometers to measure air (at 1-m above ground) and ground (soil surface in the sun) temperatures at the start and end of each repeated survey. Three experienced observers completed $99.6 \%$ of surveys.

We used two general analytical approaches to address our goals. First, to describe the dynamics of populations, we used a modeling approach that explicitly considered the detection process. This approach accounted for the fact that temporal variation in observed lizard counts could be driven by short-term differences in activity levels, variation in detection probability among habitats, as well as changes in true abundance. Second, to assess the influence of climatic flux on populations, we developed a small set of research hypotheses to explain these processes based on the biology of the system, constructed statistical models to represent hypotheses, and used model-selection procedures to assess evidence among models.

\section{Population dynamics}

To estimate population growth rates and abundances, we used $N$-mixture models generalized for open populations (Royle, 2004; Dail and Madsen, 2011). These hierarchical models use spatial and temporal replication in count data to jointly estimate abundance and detection probability, and attribute observation error to the inability to detect all individuals during sampling (Zipkin et 
al. 2014). We used a simplified version of the Dail-Madsen $N$-mixture model parameterized for exponential population growth described as follows:

$$
\begin{aligned}
N_{i 1} & \sim \text { Poisson }(\gamma) \\
N_{i t} & \sim \text { Poisson }\left(\lambda, N_{i t-1}\right) \\
y_{i j t} & \sim \operatorname{Binomial}\left(N_{i t}, p\right)
\end{aligned}
$$

where $N_{i t}$ is abundance at site $i$ during year $t, \gamma$ is mean initial abundance, $\lambda$ is the finite rate of increase, $y_{i j t}$ are counts for the $j^{\text {th }}$ repeated survey, and $p$ is detection probability. In using this approach, we assumed populations were closed among repeated daily surveys but open between seasons and among years. To model the observation process, we considered the following potential covariates of detection probability: (1) dominant hydrologic regime based on vegetation differences (upland, riparian), (2) topographic formation (rocky slope, bajada, valley floor) or soil texture (fine-sand or silt, coarse-pebbles or rocks), (3) vegetation formation (desert shrubland, desert woodland, xeroriparian woodland), (4) linear and curvilinear (quadratic or $x^{2}$ ) terms for ground or air temperature (for terrestrial and arboreal species, respectively), (5) Julian day, (6) time-after-sunrise, and (7) monthly precipitation. To estimate parameters, we used the pcountOpen function in the unmarked library in R (Fiske and Chandler 2011; R Core Development Team, 2013). We used Akaike's information criterion adjusted for sample size $\left(\mathrm{AIC}_{\mathrm{c}}\right)$ to select optimal observation models for each species, and then fit process models. We analyzed data for each season separately because populations of some species in each season are the results of reproduction in different years, which made the assumption of closure between seasons unrealistic. We excluded observations of juveniles that had not recruited into the adult or sub-adult populations, and from transects where each focal species was never detected. 


\section{Climatic variation and hypotheses}

To describe regional climatic variation across time and space, we used data on precipitation $(P)$ from 17 weather stations and temperature $(T)$ from 9 of those stations located throughout OPCNM (Fig. 1). To quantify climatic variation experienced by lizards, we matched each transect with the most similar weather station based on proximity and elevation. Missing values were estimated with linear mixed effects models (LMEM) similar to eq. 4, which included the location and elevation of weather stations as covariates and data from 6 additional stations located at similar positions along the slope gradient to account for cold-air inversions.

To assess temporal trends in $P$ and $T$, we used LMEM described as follows:

$$
y_{i t}=\left(\beta_{0}+b_{0 i}\right)+\beta_{1} x_{i t}+\varepsilon_{i t}, \quad \varepsilon_{i t} \sim \mathrm{N}\left(0, \sigma^{2}\right)
$$

where $y_{i t}$ is a vector of the climatic attribute of interest, $\beta_{0}$ is an intercept for the population, $b_{0 i}$ is a vector of random intercepts for each weather station, $\beta_{1}$ is a trend parameter for a fixed year effect, $x_{i t}$ indicates the year of observation, and $\varepsilon_{i t}$ is an error term that has a normal distribution with a mean of zero and variance $\sigma^{2}$ that measures observation error. To adjust for temporal autocorrelation, we considered various autoregressive-moving-average structures $(p, q=0-3)$ and used restricted maximum likelihood (REML) and $\mathrm{AIC}_{\mathrm{c}}$ to determine optimal structures. In all cases, autocorrelation functions confirmed the independence of residuals. We fit models with the nlme library in R (Pinheiro et al., 2014).

To assess the influence of climatic attributes on spatiotemporal variation in lizard abundance, we developed four research hypotheses. Local variation in $P$ and $T$ could affect abundance directly through energetic and thermoregulatory constraints, or indirectly by affecting food or heterospecific predators and competitors. In arid environments, $P$ often drives rapid increases in plant biomass, seed production, and insect abundance, which bolsters food availability for small 
vertebrates, increasing their abundance at short lag times and predator abundance at longer lag times (Beatley, 1969; Holmgren et al., 2006). Thus, the prey enhancement hypothesis predicts lizard abundance in year $t$ increase with $P$ in year $\approx t-1$. Similarly, the predation hypothesis predicts lizard abundance in year $t$ decreases with $P$ at longer lag times or is highest at moderate $P$ but declines at low and high $P$. High average maximum daily temperatures $\left(T_{\max }\right)$ during the warm season could restrict foraging and other lizard activities thereby reducing reproduction or survival, and hence abundance the following year (Kearney et al., 2009; Sinervo et al., 2010). Thus, the heat stress hypothesis predicts high $T_{\max }$ during the warm season reduces abundance the following year. Low average minimum daily temperatures $\left(T_{\min }\right)$ could have varying influences on lizards. Low $T_{\min }$, for example, could restrict emergence from winter dormancy, foraging, and ovarian processes in ways that reduce body condition, growth, reproduction or survival, and hence abundance at lag times of $\approx 1-1.5$ years, especially for winter-active species (Asplund and Lowe, 1964). Alternatively, high $T_{\min }$ could reduce the quality of low-temperature thermoregulatory refugia and increase energetic costs of maintenance metabolism during dormancy or nocturnal inactivity in ways that diminish energy reserves for reproduction and hence abundance the following year (Zani, 2008; Zani et al., 2012). Thus, these cold-effects hypotheses, predict decreasing or increasing $T_{\min }$ reduces abundance at lag times of $\approx 1-1.5$ years. Although extreme low $T_{\min }$ could cause freeze mortality and reduce abundance at shorter lag times, reptiles' super-cooling capacity and tendency to overwinter at depths below ground that provide strong thermal buffering suggests this is unlikely (Cowles, 1941; Lowe et al., 1971; but see Tinkle, 1967; Vitt, 1974), which exploratory analyses confirmed.

Despite similarities among species, interspecific differences in breeding phenology, age of maturity, and other traits should influence the seasonal periods and lag times of associations between abundances and $P$ or $T$. Thus, in developing models to represent hypotheses, we first 
evaluated the effects of weather during different seasonal periods and over a small set of likely lag times, which we based on the biology of each species (Appendix S1). For the prey enhancement hypothesis, we considered $P$ during the prior fall (Sept-Oct of prior yr; $P_{\text {fall }}$ ), coolseason (Nov 2-yrs prior to Apr of prior yr; $P_{\mathrm{cs}}$ ), warm-season (May-Oct of prior yr; $P_{\mathrm{ws}}$ ), and annually $\left(P_{\mathrm{cs}}+P_{\mathrm{ws}}=P_{\mathrm{yr}}\right)$, and for the predation hypothesis we averaged values of $P_{\mathrm{yr}}$ from the prior 2-4 years $\left(P_{\mathrm{yr}-234}\right)$. For the heat stress hypothesis, we considered $T_{\max }$ during Apr-May, AprJun, Jul-Aug, and Jul-Sept of the prior year and Sept 2-yrs prior, because they could influence activity, reproduction, or recruitment (Appendix S1). For the cold-effects hypotheses, we considered $T_{\min }$ during Nov-Mar, Mar-May, May-Jul, and annually (Nov-Oct) at lag times of $\approx 1$ or 1-1.5 yrs. Finally, because the side-blotched lizard is largely an annual species, we lagged weather factors an additional time step when assessing associations with spring abundance.

To evaluate support for our hypotheses, we developed statistical models to represent hypotheses and used an information-theoretic approach based on $\mathrm{AIC}_{\mathrm{c}}$ and $\mathrm{AIC}_{\mathrm{c}}$ weights $\left(w_{i}\right.$; e.g., probability a model is the best approximating model) to assess support among models (Burnham and Anderson 2002). Models within $\approx 2 \Delta \mathrm{AIC}_{\mathrm{c}}$ units were considered competitive except when they included uninformative parameters. As a general strategy, we first compared models that included only single related weather factors linked to each hypothesis at the lag times and seasonal periods noted above. In assessing these preliminary models, we considered each factor on the untransformed and logarithmic scales, quadratic terms for $T_{\min }$ and $P_{\mathrm{yr}-234}$ to assess curvilinear associations, and used models with the lowest $\mathrm{AIC}_{\mathrm{c}}$ to represent hypotheses. Second, we considered models that included combinations of hypotheses, after first assessing pair-wise correlations between factors linked to each hypothesis, which were low in all cases $(|r|=0.04-0.40 ;$ Appendix S2). Finally, we refined the top-ranked model for each species by assessing the effects of including, excluding, or changing terms. 
To fit models, we used LMEM similar to eq. 4 and fit $P$ and $T$ as fixed effects. We fit transect and year as crossed random intercepts, which REML and $\mathrm{AIC}_{\mathrm{c}}$ confirmed was optimal, used autocorrelation functions to confirm independence of residuals, and fit models with the lme4 library in R (Bates et al. 2015). As response variables, we used log-transformed transectand season-specific estimates of abundances from our best $N$-mixture models that were corrected for variation in detection probability. To assess relative effect magnitudes of factors linked to each hypothesis, we computed standardized (e.g., $z$-scored) regression coefficients for a full model that included factors linked to all four hypotheses for each focal species. Because observed associations between abundances and $P$ or $T$ could be driven by coincidentally cooccurring long-term trends (Grosbois et al. 2008), we further evaluated effect magnitudes with residual regressions of detrended variables. We excluded one high-elevation transect where most focal species were rare because estimates of $T$ were outliers.

\section{Results}

\section{Effort and observations}

Over 25 years, we completed 2,847 surveys in spring and 2,701 surveys in summer, and detected 14,305 individuals of the five focal species (Table 1). Each year, we surveyed an average of 23.5 $\pm 1.5( \pm \mathrm{SE})$ transects in spring and $23.3 \pm 1.5$ in summer. Across all years, we visited each of the 32 transects over an average of $18.2-18.4 \pm 0.7$ years.

All eight potential covariates of detection probability were associated with the observation process of at least one species, but temperature effects were often greatest and consistently curvilinear (Table S3, Figs. S3, S4). Detection probability of tiger whiptail and side-blotched lizard peaked sharply at moderate temperatures, whereas that of the ornate tree lizard and zebratailed lizard peaked at lower and higher temperatures, respectively (Fig. S3). Detection 
probability often increased with precipitation in spring but not during the summer monsoon, and the influence of Julian day varied widely among species and seasons.

\section{Population dynamics}

Abundance dynamics and population growth rates varied among species but were often similar between seasons for a given species and also among species with similar life history traits (Table 1, Fig. 2). Among terrestrial species, abundance of a winter-spring breeder increased across time while that of two spring-summer breeders declined. In contrast, there was no evidence of systematic declines of arboreal species (Table 1). Specifically, abundances of the side-blotched lizard increased markedly by an estimated $237-285 \%$ over time, while the larger tiger whiptail and zebra-tailed lizard declined by an estimated $60-64 \%$ based on spring surveys (Table 1). Although there was much less evidence of declines during summer (Table 1), after year 2000 population growth rates of both the tiger whiptail and zebra-tailed lizard were negative in virtually all years in both seasons (Fig. 2). Among arboreal species, there was some evidence that abundance of the tree lizard increased (Table 1), whereas abundance of the more terrestrial desert spiny lizard generally decreased after year 2000 (Fig. 2). More generally, abundances of most species were relatively high between 1999 and 2001, and again between 2006 and 2008 .

Abundance dynamics among similar and dissimilar species were often correlated in expected directions. For example, both terrestrial warm-season breeders displayed similar dynamics in both seasons $(r=0.55-0.69, p \leq 0.004, n=25$; for correlations among annual abundance estimates), with similar patterns for both arboreal species in spring $(r=0.80, p<0.001)$ but not summer $(r=0.01, p \geq 0.96)$. Dynamics of the terrestrial, winter-spring breeding side-blotched lizard, however, were negatively correlated with that of larger terrestrial, warm-season breeding 
tiger whiptail in spring $(r=-0.67, p<0.001)$, and positively correlated with dynamics of the arboreal tree lizard in spring $(r=0.39, p=0.057)$ and especially summer $(r=0.71, p<0.001)$.

\section{Climatic variation}

Precipitation $(P)$ during all seasonal periods declined across the study period, but declines in cool-season $P$ occurred at a rate $>2$-times greater than that during the monsoon-influenced warm season (Table 2, Fig. 3). Mean maximum temperature $\left(T_{\max }\right)$ during the warm season increased across time, especially in late summer (Fig. 4), but there was little evidence $T_{\min }$ increased (Table 2). Cyclical temporal changes in cool-season $T_{\min }$, and to a lesser extent mean annual $P$ during the prior 2-4 years, suggested the influence of global climate patterns (e.g., ENSO).

Associations between local spatiotemporal variation in abundances and both $P$ and $T$ were often strong, with evidence for the combined influence of factors linked to all four hypotheses highest for three of five focal species (Table 3). As predicted by the prey enhancement hypothesis, abundances of all species increased with precipitation at short lag times (Table 3), but associations were relatively weak for the side-blotched lizard (Table 4). Abundance of the tree lizard, for example, increased by an estimated $0.14 \pm 0.06 \%$ with each $1 \mathrm{~mm}$ increase in warm-season $P$, with similar associations for the tiger whiptail and zebra- tailed lizard. Associations for other species, however, were with cool-season or fall $P$ (Table 4).As predicted by the predation hypothesis, abundances of the tiger whiptail and tree lizard increased up to moderate levels of $P$ at a 2-4 year lag time, but declined markedly thereafter (Fig. 5). In contrast, but also as predicted, abundance of smaller side-blotched lizard decreased linearly and markedly with increasing $P$ at this longer lag time (Fig. 5). Associations between abundances and $P$ at both short and long lag times persisted and sometimes increased in significance based on detrended estimates (Table 4). Thus, variation in abundances that remained after removing linear time 
effects was explained by variation in $P$, and associations were not driven by co-occurring temporal trends. Where significant, $P$ at long lag times had greater relative effects than $P$ at short lag times (based on standardized regression coefficients), but effect magnitudes declined in one case based on detrended estimates (Table 4).

As predicted by the heat stress hypothesis, abundances of the zebra-tailed lizard and especially tree lizard declined with increasing $T_{\max }$ during prior warm seasons (Table 4). Contrary to predictions, however, other species showed the opposite pattern. As predicted by the cold-effects hypotheses, abundances of four species declined markedly with increasing $T_{\min }$, with similar patterns for desert spiny lizard from low to moderate $T_{\min }$ (Table 4). Associations between abundances and $T_{\min }$ were strongest during winter for the side-blotched lizard and tree lizard or just prior or during the breeding season for the tiger whiptail and zebra-tailed lizard. Associations with $T_{\min }$ were greater than that for $T_{\max }$ for three species but lower for the tree lizard and zebra-tailed lizard. Importantly, associations between abundances and $T$ largely remained significant and relative effect magnitudes remained similar based after detrending data (Table 4).

\section{Discussion}

We documented marked and divergent long-term changes in abundances of five common species of diurnal lizards in the Sonoran Desert over 25 years. Given the warming and drying trends we observed over the study period, simple expectations might be that all species would decline, or that species with high temperature preferences $\left(T_{\mathrm{b}}\right)$ and adaptations to cope with extreme aridity might fare best. Few patterns, however, matched these expectations. Although the species most associated with aridlands increased markedly despite low $T_{\mathrm{b}}$ (side-blotched lizard), species with high $T_{\mathrm{b}}$ generally declined whereas other species with lower $T_{\mathrm{b}}$ that are associated with more 
mesic environments, largely remained stable. Thus, abundance dynamics were variable and explicable based largely on differences in microhabitat use, breeding phenology, and other species' traits. In general, species that increased or remained stable are arboreal and thus mainly shade-dwelling, or breed during winter or spring, which are traits that tend to insulate individuals from abiotic extremes. In contrast, species that declined use more open microhabitats on the ground and breed mainly during summer, which are traits that augment exposure to abiotic extremes. Such trait-mediated responses to climatic variation have been reported for other taxa (e.g., Lavergne et al., 2006; Diamond et al., 2011), are consistent with the anticipated effects of climate change on ectotherms (Kearney et al., 2009; Huey et al., 2012; Huey and Tewksbury, 2010; Sinervo et al., 2010), but had not been described over the long term in aridlands.

Spatiotemporal changes in abundances were highly associated with climatic variation but the influence of different climatic attributes varied, sometimes in novel ways. Despite the increasingly extreme environment we considered and global threats to ectotherms posed by climate warming (Sinervo et al., 2010; Kearney, 2013), abundances were often weakly and sometimes positively associated with daily maximum air temperatures $\left(T_{\max }\right)$ during the warm season. In contrast, abundances of all species declined, often markedly, with increasing daily minimum air temperatures $\left(T_{\min }\right)$ in either the cool or warm season, which to our knowledge has not been reported for ectotherms. As commonly found in populations of small desert consumers, however, abundances increased with precipitation $(P)$ at short lag times (Whitford and Creusere, 1977; Lima et al., 2002, 2008) due likely to bottom-up processes that augment food resources (Rosenzweig, 1968; Holmgren et al. 2006), but these associations were often relatively weak. At longer lag times, however, abundances often declined after periods of high $P$ likely due to the top-down effects of predators and other biotic processes. Thus, whereas some patterns we observed are consistent with the anticipated influence of climatic flux on desert ectotherms, our 
results suggest a complexity of direct and indirect effects driven by various biotic and abiotic factors (Ockendon et al., 2014).

\section{Effects of Maximum Daily Air Temperatures $\left(T_{\max }\right)$}

By limiting activity to avoid lethally high environmental temperatures, rising breeding-season temperatures linked to climate change are expected to drive pervasive declines in populations of diurnal lizards (Huey et al. 2009; Sinervo et al. 2010). Nonetheless, associations we observed between abundances and $T_{\max }$ varied widely among species and were sometimes positive or focused in seasons other than mid-summer, suggesting the influence of climate warming on lizards may be more complex than previously envisioned. Abundances of the tiger whiptail and desert spiny lizard, for example, increased with rising $T_{\max }$ during spring, suggesting warmer early spring conditions promote foraging activity and reproduction. Collectively, the direction and timing of associations between abundances and $T_{\max }$ varied with habitat use, foraging behavior, and other species' traits. Only the most arboreal species, the tree lizard, showed the expected strong negative association between abundance and $T_{\max }$ during the breeding season (Sinervo et al. 2010), which coincides with peak temperatures of mid-summer. Despite these patterns and low $T_{\mathrm{b}}$, abundance of the tree lizard did not decline over time. This species' highly arboreal lifestyle may limit access to subterranean thermal refugia commonly used by terrestrial species to avoid extreme heat, thereby augmenting susceptibility to $T_{\max }$. The widely foraging tiger whiptail, however, may be able to avoid risks associated with $T_{\max }$ by moving from open microhabitats to cooler, shade-moderated thermal environments under trees, shrubs, and leaf litter (Ryan et al., 2015). In contrast, the sit-and-wait foraging strategy of the zebra-tailed lizard, which involves fast running on open ground, offers fewer options to compensate for rising operative environmental temperatures $\left(T_{\mathrm{e}}\right)$ via shade utilization, thus explaining observed 
negative associations with $T_{\max }$. However, both of these species declined. Thus, observed associations between abundances and $T_{\max }$ may not be directly linked to the dynamics of some focal populations in expected ways.

Absences of the anticipated effects of $T_{\max }$ may be due to the ways different microhabitats modulate $T_{\mathrm{e}}$ experienced by individuals (Sears and Angilletta, 2015). For example, variation in $T_{\max }$ is likely highly correlated with $T_{\mathrm{e}}$ in the shaded woodland environments occupied by the tree lizard, thus explaining marked negative associations we observed. For terrestrial species, however, $T_{\max }$ may not effectively quantify $T_{\mathrm{e}}$ because it is strongly linked to substrate (versus 3 air) temperatures, which are determined largely by solar insolation. Such relationships could explain a lack of predicted associations, and suggest the importance of shade and need for more focused studies that integrate monitoring $T_{\mathrm{e}}$ among various microhabitats (Dzialowski, 2005).

The influence of $T$ or $P$ on abundances, and more generally, differences in dynamics among species may also be driven by the direct effects of climate on vegetation. In aridlands, most diurnal lizards use shade provided by vegetation to sustain activity and avoid risks of lethal temperatures (Cowles and Bogert, 1944; Huey, 1982). Thus, higher levels of recent droughtinduced mortality of smaller plants such as shrubs and sub-shrubs (McAuliffe and Hamerlynck, 2010), which provide important sources of shade for terrestrial lizards, may explain declines of the tiger whiptail and other similar species. In contrast, over the same period in our region, larger deep-rooted trees declined at lower rates and hence generally persisted (McAuliffe and Hamerlynck, 2010), possibly explaining greater stability of arboreal populations. Because the tree lizard in our region is at the margins of its geographic range and already near tolerance limits, expected increases in mortality of long-lived trees linked to climate change (Ackerly et al. 2015) suggest future declines are likely. If such indirect effects mediated by vegetation are operating, they could influence the lag times and seasonal periods of associations between 
abundances and $T$ or $P$, and drive a complexity of patterns.

Given the intricacy of ways $T_{\max }$ and other climatic attributes can influence populations and their habitats, we recognize that identifying the drivers of various associations is challenging. For the side-blotched lizard, for example, abundance increased with $T_{\max }$ during mid to late summer, when most individuals are non-reproducing sub-adults, and when terrestrial habits and low $T_{\mathrm{b}}$ constrain activity to cooler morning hours. Such facts make observed associations difficult to explain physiologically and suggest the importance of biotic interactions.

\section{Effects of Minimum Daily Air Temperature $\left(T_{\min }\right)$}

Studies of the influence of climate change on ectotherms focus on $T_{\max }$, whereas potential threats posed by rising $T_{\min }$ have been largely ignored. We hypothesized extreme values of $T_{\min }$ could reduce lizard abundances by restricting, or possibly enhancing activity or emergence from winter dormancy, or by degrading low-temperature thermal refugia in ways that augment costs of maintenance metabolism during periods of seasonal dormancy or nocturnal inactivity. We found marked and consistently negative associations between abundances and rising $T_{\min }$ for all five focal species. Despite the relative novelty of these patterns, core aspects of lizard behavior and thermal biology suggest a mechanism we proposed is plausible. Rising $T_{\min }$ and $T_{\mathrm{e}}$ can increase energetic costs of maintenance metabolism if inactive, non-foraging individuals experience physiologically costly body temperatures (Patterson and Davies, 1978; Zani, 2008; Zani et al., 2012; Clarke and Zani, 2012; Brischoux et al., 2016). In ectotherms, metabolic activity rises exponentially with temperature and consumes energy important for growth, reproduction, and other processes, thereby requiring additional activity and risk to acquire lost energy (Bennett and Dawson, 1976; Huey and Slatkin 1976; Adolph and Porter, 1993). Metabolic and water-loss costs of high $T_{\min }$ may be especially large for small juveniles with low fat stores and high 
surface-to-volume ratios (Walker et al., 2015), although other processes may be involved. Thermal physiological constraints outside the breeding season, for example, can affect developmental processes in the reproductive cycle and elsewhere (Mendez de la Cruz et al., 2015). Although additional study is needed to understand mechanisms by which $T_{\min }$ influences populations, patterns we observed suggest $T_{\min }$ was more important than $T_{\max }$ in driving past dynamics. Whereas versatile behavioral repertoires combined with sufficient microhabitat diversity may buffer lizards from ambient $T_{\max }$ during day, less behavioral plasticity during coolseason dormancy and nocturnal inactivity could constrain compensating for deleterious metabolic costs of rising $T_{\min }$. Regardless, patterns we observed have grave implications for aridland ectotherms because rising $T_{\min }$ is among the strongest documented trends linked to both regional and global climate change, especially during cooler months (Easterling et al., 1997, 2000; Weiss and Overpeck, 2005) that correspond to the timing of some associations we observed. More broadly, rising nighttime temperatures can have unexpected negative effects on other taxa such as plants via increased water loss that could interact with $\mathrm{CO}_{2}$ concentrations (Yamori et al., 2014; Zeppel et al., 2014), which may be especially pronounced in aridlands (Bronson et al., 2011; Williams et al, 2014).

Interestingly, biphasic, sinusoidal temporal fluxes in $T_{\min }$ during the study period were somewhat similar to temporal changes in abundances of some lizard populations. We presume such patterns are linked to ENSO that influences both cool-season $P$ and $T_{\min }$, which were significantly but relatively weakly correlated. Despite expected relationships between abundances and cool-season $P$ driven by its influence on food availability (Whitford and Creusere, 1977; Anderson, 1994), we only observed strong associations with $T_{\min }$. Thus, the effect of cool-season $P$ may be masked, possibly by biotic interactions with species that benefit from wet winters. We suspect observed associations with $T_{\min }$ were driven by a complexity of 
biological processes interacting with both global climate phenomenon and the local weather patterns they create.

\section{Precipitation $(P)$}

In arid, resource-limited environments, the positive bottom-up effects of $P$ on populations of small vertebrates have been observed nearly worldwide (Whitford and Creusere, 1977; Lima et al., 2002; Holmgren et al., 2006). In these systems, $P$ drives rapid increases in plant biomass, seed production, and insect abundance, creating resource pulses that directly bolster food availability for small consumers, thus augmenting reproductive output and subsequently abundances at lag times of $\approx 0.5-1.5$ years depending on their life history (Beatley, 1969; Dunham, 1980; Anderson, 1994; Jaksic, 2001; Lima et al., 2002, 2008). Predator populations respond indirectly to these resources pulses at longer lag times of typically two or more years (Jaksic et al., 1992; Dennis and Otten, 2000; Lima et al., 2002; Letnic et al., 2005). More locally in the Sonoran Desert, increases in reproductive output and abundance of snakes, raptors, and other lizard predators after periods of high $P$ match these patterns and are consistent with the lag times we used as a proxy for the hypothesized influence of predation (Rosen, 2000; Flesch, 2014; Flesch et al., 2015).

Accordingly, we found that abundances of all species increased with $P$ at short lag times, although the strength, timing, and seasonal periods of associations varied among species likely due to differences in breeding phenology and perhaps age to maturity. Associations for the sideblotched lizard were relatively weak and with fall $P$, which likely augments resources at times of peak reproduction in winter and spring when energy demands are high. At a more arid site in the Mohave Desert, however, Turner et al. (1982) found stronger positive associations between abundance of the side-blotched lizard and winter $P$. In contrast, but consistent with their breeding 
phenology, associations for larger spring-summer breeders were strongest during the warm season indicating the importance of the summer monsoon. Both of these species also showed strong correlations in abundance dynamics, as did the two smaller, early maturing species. However, during an extreme drought culminating in 2002, dynamics of smaller species varied somewhat with very low abundance of the side-blotched lizard in spring increasing the summer following its winter-spring breeding period, with similar but more delayed responses by the summer-breeding tree lizard. Thus, shifting patterns of fall, winter, and summer $P$ under future climates may differentially influence species based on their breeding phenology.

At longer lag times that we hypothesize are linked to variation in predator populations, abundances of three lizard species were significantly higher at moderate $P$ and declined markedly at lower and higher $P$. Abundance of the side-blotched lizard, however, declined linearly and markedly with increasing long-term $P$. This pattern is consistent with strong documented effects of predation on the side-blotched lizard by larger lizard species, including those considered here, and by other small predators that can depress population sizes (Turner et al. 1982). Additionally, limited defenses (Tinkle, 1967; Sinervo and Doughty, 1996), and a diverse predator community in our region (Rosen, 2007) likely augment sensitivity of the sideblotched lizard to predation.

Despite evidence for the prey enhancement and predation hypotheses, we caution that the complexity of the influence of $P$ at different lag times does not entirely differentiate bottom-up from top-down processes, and that observed associations may be driven by other processes. For example, many lizard-eating snakes in our region respond rapidly to rainfall by increasing foraging activity, which likely augments predation pressure on lizards long before resourcemediated increases in snake abundance occur (George et al., 2015). Moreover, $P$ can affect bottom-up resource pulses at longer lag times than we considered (Barrows and Allen 2009; 
Barrows 2012). Such processes may partly mask the effects of $P$ at short lag times and explain higher effect magnitudes of $P$ at longer lag times. Thus, abundance increases of lizards from low to moderate levels of long-term $P$ are likely driven by both prey enhancement and low predation pressure at times when populations are small and hence growing in a density-independent manner. Conversely, declining abundances from moderate to high levels of long-term $P$ are likely driven by mounting predation pressure, and by endogenous density-dependent feedbacks and other processes.

Interspecific competition may also contribute to observed associations between abundances and $P$, and more generally, to differences in dynamics among species. Experimental studies of lizards in continental aridlands, however, generally suggest small (Cuellar, 1993; Price et al. 1993) or fluctuating (Dunham 1980) influences of competition during periods of resource scarcity. For the side-blotched lizard, however, strong linear declines in abundance with increasing long-term $P$ may be attributable to reduced competitive interactions with larger terrestrial species that declined, and contributed to a nearly 3 -fold increase in abundance we observed over time. Regardless, the relative contribution of top-down, bottom-up, and endogenous processes in driving dynamics we observed are not entirely clear based on our results.

\section{Population Dynamics, Climate, and Species' Traits}

Patterns we observed suggest a diversity of factors that influence the exposure and sensitivity of individuals to climatic variation and interactions with other species drove dynamics. Such factors include intrinsic, trait-mediated responses to climatic flux, as well as extrinsic, biotic and environmental drivers such as predation, food availability, and vegetation resources linked to the quantity and quality of microhabitats. Intrinsic factors that influence individual exposure and 
sensitivity to a changing environment include microhabitat use, thermal physiology, reproductive phenology, time to maturity, and the ability to evade predatory and competitive interactions with other species. Arboreal species, for example, that occupy shaded and thus thermally buffered habitats created by large trees, which are less susceptible to drought, showed no evidence of decline despite an increasingly extreme environment and observed negative associations with warm-season $T_{\max }$. In contrast, two dominant terrestrial spring-summer breeders with high $T_{\mathrm{b}}$, activity times focused during the heat of day, and that depend on shade provided by smaller shrubs and sub-shrubs, which are more vulnerable to drought (McAuliffe and Hamerlynck, 2010), declined likely due to the influence of an increasingly harsh environment on vegetation and food resources. Marked increases in a third terrestrial species that has low $T_{\mathrm{b}}$ and avoids the heat of summer by breeding in winter and spring, and by focusing activity during cool early mornings (Asplund and Lowe, 1964; Tinkle, 1967; Pianka, 1986), suggest phenological and physiological traits that reduce exposure to abiotic extremes drove these dynamics. Because this later species, the side-blotched lizard, is smaller and highly susceptible to predation, including that by larger, more dominant terrestrial species that declined (Turner et al., 1982), biotic interactions likely also contributed substantially to dynamics. Such a broad array of responses to climatic flux that include both the direct and indirect effects of climate on habitat resources and biotic interactions, will continue to drive a complexity of patterns in the future (Kearney et al., 2009; Huey et al., 2012; Ockendon et al., 2014). Identifying the mechanisms and relative roles of various processes in driving these dynamics, and devising management strategies focused on the most threatening processes will require additional study.

Broad changes in the lizard assemblage we studied reflect complex community-wide responses to climatic variation that over time trended toward conditions expected to be more frequent in the future. Declines of some terrestrial species we observed are consistent with global 
trends for other reptile populations that have been attributed to climate change (Reading et al. 2010, Sinervo et al. 2010). These changes are also consistent with similar trends for many other taxa in this and other arid regions of western North America (Barrows, 2006; Zylstra et al., 2012; Flesch, 2014; Lovich et al., 2014; Cruz-McDonnell and Wolf, 2015), and have broad implications for conservation and management in aridlands worldwide. However, we found a range of dynamics that included declines of ecologically dominant species that are adapted to aridity, fluctuations without systematic trend of species associated with more mesic environments that occur near the limits of their range boundaries, and major increases of one species that is dominant in increasingly arid regions to the west of our study area. Whereas some associations between abundances and climatic flux that we observed were expected and widely known in aridlands (e.g., positive effects of $P$ on food resources), others were unexpected (e.g., small or positive effects of increasing $T_{\max }$ ) or novel (e.g., universally negative effect of increasing $\left.T_{\min }\right)$. Past dynamics together with anticipated increases in temperature and drought (Seager et al., 2007, Garfin et al., 2013; Cook et al. 2015) will have large, complex effects on this and other communities of aridland ectotherms.

\section{Acknowledgements}

We thank the U.S. National Park Service (NPS) for support and for developing monitoring in OPCNM, especially superintendents H. Smith and B. Range, and Chief of Resources B. Mikus, J. Barnett, P. Rowland, and R. Morawe. C. Connor and A. Pate of NPS gathered the vast majority of field data, helped design protocols, and sustained efforts across many years despite challenges. C. Lowe, P. Bennet, Y. Petryszyn, P. Warren, R. Johnson, E. Wirt, M. Baker, G. Rufner, and K. Kingsley assisted program design, and C. Connor, A. Pate, T. Tibbitts, J. Barnett, H. Smith, P. Rowland, B. Mikus, and D. Fenn managed data. We thank S. Hejl for administrative 
support, A. Swanson for programming assistance, and A. Pate for designing Fig. 1. Two anonymous reviewers commented on drafts of the manuscript.

\section{References}

Ackerly DD, Cornwell WK, Weiss SB, Flint LE, Flint AL (2015) A geographic mosaic of climate change impacts on terrestrial vegetation: which areas are most at risk? PLoS ONE 10, e0130629.

Adolph, SC, Porter WP (1993) Temperature, activity, and lizard life histories. American Naturalist 142, 273-295.

Anderson RA (1994) Functional and population responses of the lizard Cnemidophorus tigris to environmental fluctuations. American Zoologist, 34, 409-421.

Angilletta MJ Jr (2009) Thermal adaptation: a theoretical and empirical synthesis. Oxford: Oxford University Press.

Asplund KK, Lowe CH (1964) Reproductive cycles of the iguanid lizards Urosaurus ornatus andUta stansburiana in southeastern Arizona. Journal of Morphology 115, 27-33.

Barrows CW (2006) Population dynamics of a threatened sand dune lizard. Southwestern Naturalist, 51, 514-523.

Barrows CW (2012) Temporal abundance of arthropods on desert sand dunes. Southwestern Naturalist 57, 263-266.

Barrows CW, Allen MF (2009) Conserving species in fragmented habitats: population dynamics of the flat-tailed horned lizard, Phrynosoma mcallii. Southwestern Naturalist 54, 307-316. Barrows CW, Allen MF (2010) Patterns of occurrence of reptiles across a sand dune landscape. Journal of Arid Environments, 74, 186-192. 
Barrows CW, Hoines J, Vamstad MS, Murphy-Mariscal M, Lalumiere K, Heintz J (2016) Using citizen scientists to assess climate change shifts in desert reptile communities. Biological Conservation, 195, 82-88.

Bates D, Maechler M, Bolker B, Walker S (2015) Fitting linear mixed-effects models using lme4. Journal of Statistical Software, 67, 1-48.

Beatley JC (1969) Dependence of desert rodents on winter annuals and precipitation. Ecology, 50, 721-724.

Bellard C, Bertelsmeier C, Leadley P, Thuiller W, Courchamp F (2012) Impacts of climate change on the future of biodiversity. Ecology Letters, 15, 365-377.

Bennett AF (1982). Energetics of activity in reptiles. In: Biology of the Reptilia (eds Gans C, Pough FH), Vol. 13, pp. 155-199, Academic Press, New York.

Bennett A. F. and Dawson, W. R. (1976). Metabolism. In: Biology of the Reptilia (eds Gans C, Dawson, WR), Vol. 1, pp. 127-223, Academic Press, London, UK.

Blois JL, Zarnetske PL, Fitzpatrick MC, Finnegan S (2013) Climate change and the past, present, and future of biotic interactions. Science, 341, 499-504.

Bowers JE (1980) Flora of Organ Pipe Cactus National Monument. Journal of the ArizonaNevada Academy of Science, 15, 33-47.

Brischoux F, Dupoué A, Lourdais O, Angelier F (2016) Effects of mild wintering conditions on body mass and corticosterone levels in a temperate reptile, the aspic viper (Vipera aspis). Comparative Biochemistry and Physiology Part A: Molecular \& Integrative Physiology, 192, $52-56$.

Bronson, DR, English NB, Dettman DL, Williams DG (2011) Seasonal photosynthetic gas exchange and water-use efficiency in a constitutive CAM plant, the giant saguaro cactus (Carnegiea gigantea) Oecologia 167, 861-871. 
Brown, DE (ed). 1982. Biotic communities of the American Southwest: United States and Mexico. Desert Plants, 4, 1-342.

Burnham KP, Anderson DR (2002) Model selection and multimodel inference: a practical information-theoretic approach. Springer-Verlag, New York, New York.

Clarke DN, Zani PA (2012) Effects of night-time warming on temperate ectotherm reproduction: potential fitness benefits of climate change for side-blotched lizards. Journal of Experimental Biology, 215, 1117-1127.

Cook BI, Ault TR, Smerdon JE (2015) Unprecedented 21st century drought risk in the American Southwest and Central Plains, Science Advances, 1, 1-7, e1400082.

Cowles RB (1941) Observations on the winter activities of desert reptiles. Ecology 22, 125-140.

Cowles RB, Bogert CM (1944). A preliminary study of the thermal requirements of desert reptiles. Bulletin of the American Museum of Natural History, 83, 265-296.

Cruz-McDonnell KK, Wolf BO (2015) Rapid warming and drought negatively impact population size and reproductive dynamics of an avian predator in the arid southwest. Global Change Biology, 22, 237-253.

Cuellar, O (1993) On competition and natural history of coexisting parthenogenic and bisexual whiptail lizards. In: Biology of Whiptail Lizards (eds Wright,JW, Vitt LC), pp. 345-370, Oklahoma Museum of Natural History, Norman, Oklahoma.

Dail D, Madsen L (2011) Models for estimating abundance from repeated counts of an open metapopulation. Biometrics, 67, 577-587.

Dennis B, Otten MRM (2000) Joint effects of density dependence and rainfall on abundance of San Joaquin kit fox. Journal of Wildlife Management, 64, 388-400. 
Deutsch CA, Tewksbury JJ, Huey RB, Sheldon KS, Ghalambor CK, Haak DC, Martin PR (2008) Impacts of climate warming on terrestrial ectotherms across latitude. Proceedings of the National Academy of Sciences, 105, 6668-6672.

Diamond SE, Frame AM, Martin RA, Buckley LB (2011) Species' traits predict phenological responses to climate change in butterflies. Ecology 92, 1005-12.

Dunham AE (1980) An experimental study of interspecific competition between the iguanid lizards Sceloporus merriami and Urosaurus ornatus. Ecological Monographs, 50, 309-330.

Dunham AE (1993) Population responses to environmental change: physiologically structured models, operative environments, and population dynamics. In: Biotic Interactions and Global Change (eds Kareiva PM, Kingsolver JG, Huey RG), pp. 95-119, Sinauer Associates, Sunderland, MA.

Dunham AE, Grant BW, Overall KL (1989) Interfaces between biophysical and physiological ecology and the population ecology of terrestrial vertebrate ectotherms. Physiological Zoology 62: 335-355

Dzialowski EM (2005) Use of operative temperature and standard operative temperature models in thermal biology. Journal of Thermal Biology, 30, 317-334.

Easterling DR, Horton B, Jones PD et al. (1997) Maximum and minimum temperature trends for the globe. Science, 277, 364-367.

Easterling DR, Meehl GA, Parmesan C, Changnon SA, Karl TR, Mearns LO (2000) Climate extremes: observations, modeling, and impacts. Science, 289, 2068-2074.

Fiske I, Chandler R, (2011) Unmarked: an R package for fitting hierarchical models of wildlife occurrence and abundance. Journal of Statistical Software, 43, 1-23.

Flesch AD (2014) Spatiotemporal trends and drivers of population dynamics in a declining Sonoran Desert predator, Biological Conservation, 175, 110-118. 
Flesch AD, Hutto RL, van Leeuwen WJ, Hartfield K, Jacobs S (2015) Spatial, temporal, and density-dependent components of habitat quality for a desert owl, PLOS ONE, 10, e0119986.

Garfin, G, Jardine A, Merideth R, Black M, LeRoy S (eds) (2013). Assessment of climate change in the Southwest United States. A report prepared for the national climate assessment by the southwest climate alliance. Island Press, Washington, DC.

Gedir, JV, Cain JW, Harris G, Turnbull TT (2015) Effects of climate change on long-term population growth of pronghorn in an arid environment. Ecosphere, 6, 189.

George AD, Thompson FR, Faaborg J (2015) Isolating weather effects from seasonal activity patterns of a temperate North American Colubrid. Oecologia, 178, 1251-1259

Grosbois V, Gimenez O, Gaillard JM, et al. (2008) Assessing the impact of climate variation on survival in vertebrate populations. Biological Reviews, 83, 357-399.

Holmgren M, Stapp P, Dickman CR, et al (2006) Extreme climatic events shape arid and semiarid ecosystems. Frontiers in Ecology and the Environment, 4, 87-95.

Huey RB (1982) Temperature, physiology, and ecology of reptiles. In: Biology of the Reptilia (eds Gans C, Pough FH), Vol. 13, pp. 25-91, Academic Press, New York.

Huey, RB, Slatkin M (1976) Costs and benefits of lizard thermoregulation. Q. Rev. Biol., 51, $363-384$.

Huey RB, Pianka ER, Schoener TW (eds) (1983) Lizard Ecology: Studies of a Model Organism. Harvard University Press, Cambridge, Massachusetts.

Huey RB, Deutsch CA, Tewksbury JJ, Vitt LJ, Hertz PE, Álvarez Pérez HJ, Garland T (2009) Why tropical forest lizards are vulnerable to climate warming. Proceedings of the Royal Society B: Biological Sciences. 276:1939-1948. 
Huey RB, Kearney MR, Krockenberger A, Holtum, JAM, Jess M, Williams SE (2012)

Predicting organismal vulnerability to climate warming: roles of behaviour, physiology and adaptation. Philosophical Transactions of the Royal Society, 367, 1665-1679.

Jaksic, FM (2001) Ecological effects of El Niño in terrestrial ecosystems of western South America. Ecography, 24, 241-250.

Jaksic FM, Jimenez JE, S.A. Castro SA, Feinsinger P (1992) Numerical and functional-response of predators to a long-term decline in mammalian prey at a semiarid neotropical site. Oecologia 89, 90-101.

Kerr RA (2008) Global warming - climate change hot spots mapped across the United States. Science, 321, 909.

Kéry M, Dorazio RM, Soldaat L, van Strien A, Zuiderwijk A, Royle JA (2009) Trend estimation in populations with imperfect detection. Journal of Applied Ecology, 46, 1163-1172.

Kearney M, Shine R, Porter WP (2009) The potential for behavioral thermoregulation to buffer “coldblooded"'animals against climate warming. Proceedings of the National Academy Science USA, 106, 3835-3840.

Kearney RM (2013) Activity restriction and the mechanistic basis for extinctions under climate warming. Ecology Letters, 16, 1470-1479.

Knapp AK, Carroll CJW, Denton EM, La Pierre KJ, Collins SL, Smith MD (2015) Differential sensitivity to regional-scale drought in six central U.S. grasslands. Oecologia, 177, 949957.

Lavergne S, Molina J, Debussche MA (2006) Fingerprints of environmental change on the rare mediterranean flora: a 115-year study. Global Change Biology 12, 1466-78.

Letnic, M, Tamayo B, Dickman CR (2005) The responses of mammals to La Niña-associated rainfall, predation, and wildfire in central Australia. Journal of Mammalogy, 86, 689-703. 
Levy O, Buckley LB, Keitt TH, Angilletta MJ (2016) Ontogeny constrains phenology: opportunities for activity and reproduction interact to dictate potential phenologies in a changing climate. Ecology Letters, 19, 620-628.

Lima M, Stenseth NC, Jaksic FM. (2002). Food web structure and climate effects on the dynamics of small mammals and owls in semi-arid Chile. Ecology Letters, 5, 273-284.Lima M, Ernest S, Brown JH, Belgrano A, Stenseth NC (2008) Chihuahuan Desert kangaroo rats: nonlinear effects of population dynamics, competition, and rainfall. Ecology, 89, 2594-2603. Loarie SR, Duffy PB, Hamilton H, Asner GP, Field CB, Ackerly DD (2009) The velocity of climate change. Nature, 462, 1052-1055.

Lovich JE, Yackulic CB, Freilich J, et al. (2014) Climatic variation and tortoise survival: Has a desert species met its match? Biological Conservation, 169, 214-224.

Lowe CH, Lardner PJ, Halpern EA (1971) Supercooling in reptiles and other vertebrates. Comparative Biochemistry and Physiology, 39A, 125-135.

McAuliffe JR, Hamerlynck EP (2010) Perennial plant mortality in the Sonoran and Mojave Deserts in response to severe, multi-year drought. Journal of Arid Environments. 74, 885896.

Mendez De La Cruz FR, Morán NLM, Ríos EA, Ibargüengoytía N (2015) Male reproductive cycles in lizards. In: Reproductive Biology and Phylogeny of Lizards and Tuatara (eds Rheubert JL, Siegel DS, Trauth SE), pp. 302-339, CRC Press.

Milstead WW (ed) (1967) Lizard Ecology: A Symposium. University of Missouri Press, Columbia, Missouri.

Moses MR, Frey JK, Roemer GW (2012) Elevated surface temperature depresses survival of banner-tailed kangaroo rats: will climate change cook a desert icon? Oecologia, 168, 257268. 
Nadeau CP, Fuller AK (2015) Accounting for multiple climate components when estimating climate change exposure and velocity. Methods in Ecology and Evolution, 6, 697-705.

O'connor MI, Holding JM, Kappel CV et al. (2015) Strengthening confidence in climate change impact science. Global Ecology and Biogeography, 24, 64-76.

Ockendon N, Baker DJ, Carr JA, et al. (2014) Mechanisms underpinning climatic impacts on natural populations: altered species interactions are more important than direct effects. Global Change Biology, 20, 2221-2229.

Overpeck J, Udall B (2010) Dry times ahead. Science, 328, 1642-1643.

Patterson JW, Davies PMC (1978) Energy expenditure and metabolic adaptation during winter dormancy in the lizard Lacerta vivipara Jacquin. Journal of Thermal Biology, 3, 183-186.

Pianka ER (1986) Ecology and Natural History of Desert Lizards. Analyses of the Ecological Niche and Community Structure. Princeton University Press, Princeton, New Jersey.

Pianka ER (1993) The many dimensions of a lizard's ecological niche. In: Lacertids of the Mediterranean Basin (eds Valakos ED, Bohme W, PerezMelado V, Maragou P), pp. 121154, Hellenic Zoological Society, University of Athens, Greece.

Pianka ER, Vitt LJ (eds) (1994) Lizard Ecology: Historical and Experimental Perspectives. Princeton University Press, Princeton, NJ.

Pinheiro J, Bates D, DebRoy S, Sarkar D and R Core Team (2014) nlme: Linear and nonlinear mixed effects models. R package version 3.1-118, http://CRAN.Rproject.org/package $=$ nlme.

Price AH, LaPointe JL, Atmar JW (1993) The ecology and evolutionary implications of competition and parthenogenesis in Cnemidophorus. In: Biology of Whiptail Lizards (eds Wright,JW, Vitt LC), pp. 371-410, Oklahoma Museum of Natural History, Norman, Oklahoma. 
R Development Core Team (2013) R: a language and environment for statistical computing.

Version 2.15.3.R Foundation for Statistical Computing, Vienna, Austria.

Reading CJ, Luiselli LM, Akani GC, Bonnet X, Amori G, Ballouard JM, Filippi E, Naulleau G,

Pearson D, Rugiero L. Are snake populations in widespread decline? Biology Letters. 2010 Jun 9:rsbl20100373.

Rosen PC (2000) A monitoring study of vertebrate community ecology in the northern Sonoran Desert, Arizona. PhD dissertation, University of Arizona, Tucson, AZ.

Rosen PC (2007) The amphibians and reptiles of the dry borderlands of northwestern Sonora and southwestern Arizona. In: Dry Borders: Great Natural Reserves of the Sonoran Desert (eds Felger RS, Broyles B), pp. 310-337, University of Utah Press, Logan, UT.

Rosenzweig ML (1968) Net primary productivity of terrestrial communities: prediction from climatological data. American Naturalist, 102, 683 -718.

Royle JA (2004) N-mixture models for estimating population size from spatially replicated counts. Biometrics, 60, 108-115.

Ryan MJ, Latella IM, Giermakowski JT, Snell H, Poe S, Pangle RE, Gehres N, Pockman WT, McDowell NG (2015) Too dry for lizards: short-term rainfall influence on lizard microhabitat use in an experimental rainfall manipulation within a piñon-juniper. Functional Ecology, 30, 964-973.

Seager R, Ting M, Held I, et al. (2007) Model projections of an imminent transition to a more arid climate in southwestern North America. Science, 316, 1181-1184.

Sears MW, Angilletta MJ (2015) Costs and benefits of thermoregulation revisited: both the heterogeneity and spatial structure of temperature drive energetic costs. American Naturalist 185, E94-E102 
Sheldon KS, Yang S, Tewksbury JJ (2011) Climate change and community disassembly: impacts of warming on tropical and temperate montane community structure. Ecology Letters, 14, 1191-1200.

Sinervo B, Doughty P (1996) Interactive effects of offspring size and timing of reproduction on offspring reproduction: experimental, maternal, and quantitative genetic aspects. Evolution, 50, 1314-1327.

Sinervo B, Mendez-de-la-Cruz F, Miles DB, et al. (2010) Erosion of lizard diversity by climate change and altered thermal niches. Science, 328, 894-899.

Smith MD (2011) An ecological perspective on extreme climatic events: a synthetic definition and framework to guide future research. Journal of Ecology, 99, 656-663.

Tinkle DW (1967) The life and demography of the side-blotched lizard, Uta stansburiana. Miscellaneous Publications (University of Michigan Museum of Zoology), 132, 1-182.

Turner FB, Medica PA, Bridges KW, Jenrich RI (1982) A population model of the lizard Uta stansburiana in Southern Nevada. Ecological Monographs, 52, 243-259

Vitt LJ (1974) Winter aggregations, size classes, and relative tail breaks in the tree lizard, Urosaurus ornatus (Sauria: Iguanidae). Herpetologica, 30, 182-183.

Vitt LJ, Ohmart RD (1978) Herpetofauna of the lower Colorado River: Davis Dam to the Mexican border. Proceedings of the Western Foundation of Vertebrate Zoology, 2, 35-72.

Vitt L, Pianka E (1994) Lizards Ecology: Historical and Experimental Perspectives, Princeton Univ. Press, Princeton, NJ.

Vitt LJ, Van Loben Sels RC, Ohmart RD (1981) Ecological relationships among arboreal desert lizards. Ecology, 62, 398-410. 
Walker S, Stuart-Fox D, Kearney MR (2015) Has contemporary climate change played a role in population declines of the lizard Ctenophorus decresii from semi-arid Australia? Journal of Thermal Biology, 54, 66-77.

Walther GR (2010) Community and ecosystem responses to recent climate change. Philosophical Transactions of the Royal Society B: Biological Sciences, 365, 2019-2024.

Weiss JL, Overpeck JT (2005) Is the Sonoran Desert losing its cool? Global Change Biology, 11, 2065-2077.

Whitford WG, Creusere FM (1977). Seasonal and yearly fluctuations in Chihuahuan Desert lizard communities. Herpetologica, 33, 54-65.

Williams DG, Hultine KR, Dettman DL (2014) Functional trade-offs in succulent stems predict responses to climate change in columnar cacti. Journal of Experimental Botany, 65, 34053413.

Yamori W, Hikosaka K, Way DA (2014) Temperature response of photosynthesis in C3, C4, and CAM plants: temperature acclimation and temperature adaptation. Photosynthesis Research, 119, $101-117$.

Zani P (2008). Climate change trade-offs in the side-blotched lizard (Uta stansburiana): effects of growing-season length and mild temperatures on winter survival. Physiological and Biochemical Zoology: Ecological and Evolutionary Approaches, 81, 797-809.

Zani PA, Irwin JT, Rollyson ME et al. (2012) Glycogen, not dehydration or lipids, limits winter survival of side-blotched lizards (Uta stansburiana). Journal of Experimental Biology, 215, 3126-3134.

Zeppel MJB, Lewis JD, Phillips NG, Tissue DT (2014) Consequences of nocturnal water loss: a synthesis of regulating factors and implications for capacitance, embolism and use in models. Tree Physiology, 34, 1047-1055. 
Zipkin EF, Thorson JT, See K, et al (2014) Modeling structured population dynamics using data from unmarked individuals. Ecology, 95, 22-29.

Zylstra ER, Steidl RJ, Jones CA, Averill-Murray RC (2013) Spatial and temporal variation in survival of a rare reptile: a 22-year study of Sonoran desert tortoises. Oecologia, 173, 107116.

\section{Supporting Information}

Additional Supporting Information may be found in the online version of this article:

Appendix S1. Phenology of climatic effects on five focal species of lizards.

Appendix S2. Correlations between climatic attributes linked to various hypotheses.

Table S3. Binomial detection models for five species of lizards.

Figure S3. Effects of continuous covariates on detection probability of lizards.

Figure S4. Effects of categorical covariates on detection probability of lizards.

Table S4. Rankings of hypothesized models that explained the effects of local weather on spatiotemporal variation in abundances of lizards 
Table 1: Trends in abundance of five focal species of diurnal lizards in Organ Pipe Cactus National Monument over 25 years (19892013). Abundances were measured along line transects 3 to 8 times per day during 1 or 2 days in both spring and summer of each year at up to 32 transects per year. Counts were modeled with hierarchical $N$-mixture models that explicitly accounted for variation in detection probability. Estimates of finite rate of population growth $(\lambda)$ are intercepts from a Poisson process model. Total percent population change $(\Delta \%)$ was estimated across all 24 time steps assuming exponential population growth.

\begin{tabular}{|c|c|c|c|c|c|c|c|c|c|}
\hline \multirow[b]{2}{*}{ Species } & \multirow[b]{2}{*}{ Season } & \multicolumn{3}{|c|}{ Sample size } & \multicolumn{5}{|c|}{ Population change } \\
\hline & & Sites & Surveys & Encounters & $\lambda$ & SE & Z & $P$ & $\Delta \%$ \\
\hline \multirow[t]{2}{*}{ Tiger whiptail } & Spring & 32 & 2,847 & 2,360 & 0.959 & 1.012 & 3.55 & $<0.001$ & -64 \\
\hline & Summer & 32 & 2,701 & 3,310 & 0.995 & 1.012 & 0.42 & 0.68 & -11 \\
\hline \multirow[t]{2}{*}{ Zebra-tailed lizard } & Spring & 29 & 2,556 & 858 & 0.963 & 1.019 & 2.01 & 0.044 & -60 \\
\hline & Summer & 27 & 2,353 & 623 & 0.979 & 1.018 & 1.15 & 0.25 & -40 \\
\hline \multirow[t]{2}{*}{ Side-blotched lizard } & Spring & 32 & 2,847 & 1,046 & 1.037 & 1.012 & 3.11 & 0.002 & 237 \\
\hline & Summer & 32 & 2,701 & 2,960 & 1.045 & 1.104 & 4.37 & $<0.001$ & 285 \\
\hline \multirow[t]{2}{*}{ Tree lizard } & Spring & 26 & 2,249 & 1,623 & 0.995 & 1.015 & 0.33 & 0.74 & -10 \\
\hline & Summer & 24 & 2,031 & 1,144 & 1.032 & 1.012 & 2.11 & 0.035 & 211 \\
\hline \multirow[t]{2}{*}{ Desert spiny lizard } & Spring & 20 & 1,835 & 182 & 1.008 & 1.018 & 0.446 & 0.66 & 121 \\
\hline & Summer & 19 & 1,662 & 199 & 0.991 & 1.020 & 0.445 & 0.66 & -19 \\
\hline
\end{tabular}


Table 2: Trends in precipitation and temperature factors considered when assessing the influence of climatic variation on lizards in Organ Pipe Cactus National Monument (OPCNM) over 25 years (19892013). Parameter estimates ( $\beta$ ) and standard errors (SE) are based on linear mixed effects models with a fixed year effect, random station effect, and autoregressive-moving-average covariance structures $(p, q=$ 0-3). Temperature $\left({ }^{\circ} \mathrm{C}\right)$ was measured at 9 stations and precipitation $(\mathrm{mm})$ was measured at 17 stations across time throughout OPCNM.

\begin{tabular}{lccccc}
\hline Factor (units) & ARMA & \multicolumn{5}{c}{ Trend } \\
\cline { 4 - 6 } & structure & & & & \\
Period & $(p, q)$ & $\beta$ & SE & $t$ & $P$ \\
\hline Precipitation (mm) & & & & & \\
Annual (Nov-2 yrs prior - Oct 1 yr prior) & 2,2 & -3.69 & 0.46 & -7.96 & $<0.001$ \\
Warm season (prior May-Oct) & 3,2 & -1.21 & 0.28 & -4.36 & $<0.001$ \\
Cool season (Nov-2 yrs prior -Apr 1 yr prior) & 2,2 & -2.70 & 0.47 & -5.75 & $<0.001$ \\
Annual (mean, 2-4 yr prior) & 0,2 & -4.30 & 0.40 & -10.69 & $<0.001$ \\
Temperature - mean maximum ( ${ }^{\circ} \mathrm{C}$ ) & & & & & \\
Spring (prior Apr-Jun) & & & & & \\
Summer (prior Jul-Aug) & 3,2 & 0.029 & 0.011 & 2.69 & 0.008 \\
Late summer (prior Sept) & 2,0 & 0.021 & 0.011 & 1.85 & 0.066 \\
Temperature - mean minimum ( ${ }^{\circ} \mathrm{C}$ ) & 3,1 & 0.040 & 0.013 & 2.99 & 0.003 \\
Annual (Nov-2 yrs prior -Oct 1 yr prior) & 3,1 & 0.017 & 0.012 & 1.35 & 0.178 \\
Winter (Nov-2 yrs prior -Mar 1 yr prior) & 2,2 & -0.006 & 0.012 & -0.52 & 0.604 \\
Early breeding season (prior Mar-May) & 3,2 & 0.009 & 0.008 & 1.09 & 0.278 \\
Breeding season (prior May-Jul) & & 0.037 & 0.021 & 1.76 & 0.080 \\
\hline & & & & & \\
\hline
\end{tabular}


Table 3: Rankings of hypothesized models that explained the influence of weather on spatiotemporal variation in abundance (In no.) of five species of diurnal lizards in Organ Pipe Cactus National Monument over a 25-year period (1989-2013). K represents the number of model parameters, $\Delta \mathrm{AIC}_{\mathrm{c}}$ is the change in $\mathrm{AIC}$ between each model and the best approximating model, and $\mathrm{Al}_{\mathrm{c}}$ weights $\left(w_{i}\right)$ are probabilities each model is the best approximating model in each model set. Only models within 6 $\triangle \mathrm{AICc}$ points are shown; other models are in Table S4. Variables representing each hypothesis are in Table 4.

\begin{tabular}{|c|c|c|c|}
\hline \multicolumn{4}{|l|}{ Species } \\
\hline Model & K & $\triangle \mathrm{AICC}$ & $w_{i}$ \\
\hline \multicolumn{4}{|l|}{ Tiger whiptail } \\
\hline Prey + predation + warm stress + cold effects & 9 & 0.00 & 1.000 \\
\hline Prey + predation + cold effects & 8 & 3.26 & 0.196 \\
\hline \multicolumn{4}{|l|}{ Zebra-tailed lizard } \\
\hline Prey + warm stress + cold effects & 7 & 0.00 & 1.000 \\
\hline Prey + cold effects & 6 & 2.42 & 0.298 \\
\hline Prey + predation + warm stress + cold effects & 9 & 3.60 & 0.165 \\
\hline Warm stress + cold effects & 6 & 3.84 & 0.146 \\
\hline \multicolumn{4}{|l|}{ Side-blotched lizard } \\
\hline Prey + predation + warm stress + cold effects & 8 & 0.00 & 1.000 \\
\hline Predation + warm stress + cold effects & 7 & 1.59 & 0.451 \\
\hline Prey + predation + cold effects & 7 & 4.31 & 0.116 \\
\hline Predation + cold effects & 6 & 5.91 & 0.052 \\
\hline \multicolumn{4}{|l|}{ Tree lizard } \\
\hline Prey + predation + warm stress + cold effects & 9 & 0.00 & 1.000 \\
\hline Predation + warm stress + cold effects & 8 & 2.41 & 0.299 \\
\hline Prey + predation + warm stress & 8 & 5.22 & 0.074 \\
\hline
\end{tabular}

Desert spiny lizard 
Prey + warm stress + cold effects

Warm stress + cold effects

Prey + predation + warm stress + cold effects

Predation + warm stress + cold effects

Cold effects

Prey + cold effects

Predation + cold effects

Prey + predation + cold effects $\begin{array}{lll}8 & 0.00 & 1.000\end{array}$

$\begin{array}{lll}7 & 1.18 & 0.555\end{array}$

$\begin{array}{lll}9 & 1.55 & 0.461\end{array}$

$\begin{array}{lll}8 & 2.29 & 0.318\end{array}$

$\begin{array}{lll}6 & 2.98 & 0.226\end{array}$

$\begin{array}{lll}7 & 3.18 & 0.204\end{array}$

$\begin{array}{lll}7 & 3.71 & 0.156\end{array}$

$\begin{array}{lll}8 & 4.29 & 0.117\end{array}$ 
Table 4: Estimated effects of precipitation $(P, \mathrm{~mm})$ and temperature $\left(T,{ }^{\circ} \mathrm{C}\right)$ on spatiotemporal variation in abundance $(\mathrm{In}$ no.) and time-detrended abundance of five species of lizards in Organ Pipe Cactus National Monument over 25 years (1989-2013). Parameter estimates ( $\beta$ ) and standard errors (SE) are from linear mixed effects models with crossed random intercepts for transect and year. Effect forms note where log (In) or quadratic $\left(x^{2}\right)$ terms fit better than linear terms, and sample sizes note the number of transects, seasons, and years for which data were available. Unstandardized parameter estimates are on the original scale whereas standardized estimates are for Z-scored factors thus illustrate relative effect magnitudes. Detrended models show effects after removing linear time effects from local abundance and weather data. Weather factors were measured at 9-17 stations across the monument. $T$-values $\geq 2$ are indicative of statistically significant relationships.

\begin{tabular}{|c|c|c|c|c|c|c|c|c|c|c|c|}
\hline \multirow[b]{2}{*}{ Species (sample size) } & & \multicolumn{5}{|c|}{ Local abundance } & \multicolumn{5}{|c|}{ De-trended local abundance } \\
\hline & & \multicolumn{2}{|c|}{ unstandardized } & \multicolumn{3}{|c|}{ standardized } & \multicolumn{2}{|c|}{ unstandardized } & \multicolumn{2}{|c|}{ standardized } & \multirow[b]{2}{*}{$t$} \\
\hline Hypotheses & Factor (period; form) & $\beta$ & SE & $\beta$ & SE & $t$ & $\beta$ & SE & $\beta$ & SE & \\
\hline \multicolumn{12}{|l|}{ Tiger whiptail (1140) } \\
\hline Prey enhancement & $P_{\text {ws }}$ (May-Oct 1-yr lag; In) & 0.183 & 0.050 & 0.111 & 0.030 & 3.63 & 0.181 & 0.044 & 0.109 & 0.026 & 4.14 \\
\hline Predation & $P_{y r}\left(\right.$ annual 2-4-yr lag; ${ }^{\wedge}$ ) & $-2.29 \mathrm{E}-05$ & 4.96E-06 & -0.578 & 0.125 & -4.62 & $-3.20 \mathrm{E}-05$ & $6.10 \mathrm{E}-06$ & -0.119 & 0.023 & -5.24 \\
\hline Warm stress & $T_{\max }$ (Apr-May 1-yr lag) & 0.067 & 0.029 & 0.104 & 0.045 & 2.31 & 0.064 & 0.026 & 0.075 & 0.036 & 2.11 \\
\hline Cold effects & $T_{\min }$ (Mar-May 1-yr lag) & -0.096 & 0.025 & -0.210 & 0.054 & -3.91 & -0.072 & 0.022 & -0.156 & 0.048 & -3.29 \\
\hline \multicolumn{12}{|c|}{ Zebra-tailed lizard (1026) } \\
\hline Prey enhancement & $P_{\text {ws }}$ (May-Oct 1-yr lag; In) & 0.169 & 0.069 & 0.102 & 0.042 & 2.45 & 0.146 & 0.066 & 0.088 & 0.039 & 2.23 \\
\hline Predation & $P_{\mathrm{yr}}$ (annual 2-4-yr lag; ${ }^{\wedge}$ ) & $-1.43 \mathrm{E}-06$ & $6.62 \mathrm{E}-06$ & -0.036 & 0.168 & -0.22 & $-4.17 \mathrm{E}-06$ & $8.50 \mathrm{E}-06$ & -0.015 & 0.031 & -0.49 \\
\hline Warm stress & $T_{\max }($ Sept 2-yr lag) & -0.085 & 0.038 & -0.114 & 0.051 & -2.22 & -0.066 & 0.036 & -0.086 & 0.047 & -1.84 \\
\hline Cold effects & $T_{\min }$ (May-Jul 1-yr lag) & -0.108 & 0.030 & -0.229 & 0.065 & -3.54 & -0.080 & 0.029 & -0.167 & 0.061 & -2.73 \\
\hline
\end{tabular}

Side-blotched lizard (1140) 


\begin{tabular}{|c|c|c|c|c|c|c|c|c|c|c|c|}
\hline Prey enhancement & $P_{\text {fall }}($ Sept-Oct 1-yr lag) & 0.002 & 0.001 & 0.072 & 0.038 & 1.91 & 0.002 & 0.001 & 0.068 & 0.036 & 1.88 \\
\hline Predation & $P_{\text {yr }}$ (annual 2-4-yr lag) & -0.50 & 0.17 & -0.138 & 0.048 & -2.89 & -0.193 & 0.186 & -0.044 & 0.043 & -1.04 \\
\hline Warm stress & $T_{\max }($ Jul-Sept 1-2 yr lag; In) & 3.30 & 1.30 & 0.079 & 0.031 & 2.55 & 2.999 & 1.292 & 0.071 & 0.031 & 2.32 \\
\hline Cold effects & $T_{\min }$ (Nov-Mar 0-2 yr lag) & -0.047 & 0.015 & -0.158 & 0.050 & -3.16 & -0.041 & 0.014 & -0.136 & 0.046 & -2.97 \\
\hline \multicolumn{12}{|l|}{ Tree lizard (890) } \\
\hline Prey enhancement & $P_{\text {ws }}$ (May-Oct 1-yr lag) & 1.37E-03 & $6.46 \mathrm{E}-04$ & 0.082 & 0.039 & 2.12 & $1.41 \mathrm{E}-03$ & $6.28 \mathrm{E}-04$ & 0.085 & 0.038 & 2.25 \\
\hline Predation & $P_{\mathrm{yr}}$ (annual 2-4-yr lag; ^²) & $-3.01 E-05$ & $6.20 \mathrm{E}-06$ & -0.78 & 0.16 & -4.86 & $-2.42 \mathrm{E}-05$ & 7.62E-06 & -0.094 & 0.029 & -3.18 \\
\hline Warm stress & $T_{\max }$ (Jul-Aug 1-yr lag; In) & -7.00 & 2.10 & -0.181 & 0.054 & -3.34 & -8.89 & 2.00 & -0.229 & 0.051 & -4.44 \\
\hline Cold effects & $T_{\min }($ Nov-Mar 1-2 yr lag; In) & -0.39 & 0.14 & -0.164 & 0.061 & -2.70 & -0.30 & 0.13 & -0.125 & 0.055 & -2.27 \\
\hline \multicolumn{12}{|l|}{ Desert spiny lizard (743) } \\
\hline Prey enhancement & $P_{c s}($ Nov-Apr 1-2 yr lag) & 0.002 & 0.001 & 0.150 & 0.090 & 1.69 & 0.046 & 0.021 & 0.146 & 0.068 & 2.15 \\
\hline Predation & $P_{\mathrm{yr}}$ (annual 2-4-yr lag; In) & 0.20 & 0.27 & 0.053 & 0.073 & 0.73 & -0.46 & 0.27 & -0.098 & 0.057 & -1.72 \\
\hline Warm stress & $T_{\max }($ Apr-May 1 yr lag; In) & 3.82 & 1.74 & 0.187 & 0.084 & 2.20 & 0.076 & 0.039 & 0.111 & 0.064 & 1.75 \\
\hline Cold effects & $T_{\min }($ Nov-Mar 1-2 yr lag; ^2) & 0.011 & 0.004 & 0.56 & 0.19 & 2.96 & 0.012 & 0.004 & 0.132 & 0.039 & 3.40 \\
\hline
\end{tabular}




\section{Figure Legends:}

Fig. 1. Distribution of survey transects for lizards, weather stations, and vegetation communities in Organ Pipe Cactus National Monument (OPCNM). Inset map shows the distribution of four of the six subdivisions of the Sonoran Desert and the transitional nature of the study area.

Fig. 2. Temporal variation in local and regional abundances of five species of lizards in spring and summer over 25 years in Organ Pipe Cactus National Monument (1989-2013). Estimates are from $N$-mixture models and are adjusted for variation in detection probability.

Fig. 3. Temporal variation in precipitation during four time periods considered when assessing the influence of climatic variation on lizard populations over 25 years in Organ Pipe Cactus National Monument (1989-2013). Estimates are from 17 weather stations located throughout the monument. Trend estimates are based on linear mixed effects models with autoregressivemoving-average structures to adjust for temporal autocorrelation. Parameter estimates and significance levels are summarized in Table 2.

Fig. 4. Temporal variation in mean maximum $\left(T_{\max }\right)$ and mean minimum $\left(T_{\min }\right)$ daily temperature during various time periods considered when assessing the influence of climatic variation on lizard populations over 25 years in Organ Pipe Cactus National Monument (1989-2013). Estimates are from at 9 weather stations located throughout the monument. Trend estimates are based on linear mixed effects models with autoregressive-moving-average structures. Parameter estimates and significance levels are summarized in Table 2. 
Fig. 5. Associations between lizard abundance and weather factors linked to four hypotheses that explained the influence of precipitation $(P, \mathrm{~mm})$ and temperature $\left(T,{ }^{\circ} \mathrm{C}\right)$ on spatiotemporal variation in lizard abundance in Organ Pipe Cactus National Monument over 25 years (19892013). Associations are shown for three species of lizards that exemplify differences in life history traits: the terrestrial, spring-summer breeding tiger whiptail; smaller, terrestrial, winterspring breeding side-blotched lizard; and the arboreal ornate tree lizard. Regression lines are from linear mixed effects models with crossed random intercepts for transect and year, and are summarized in Table 4. 


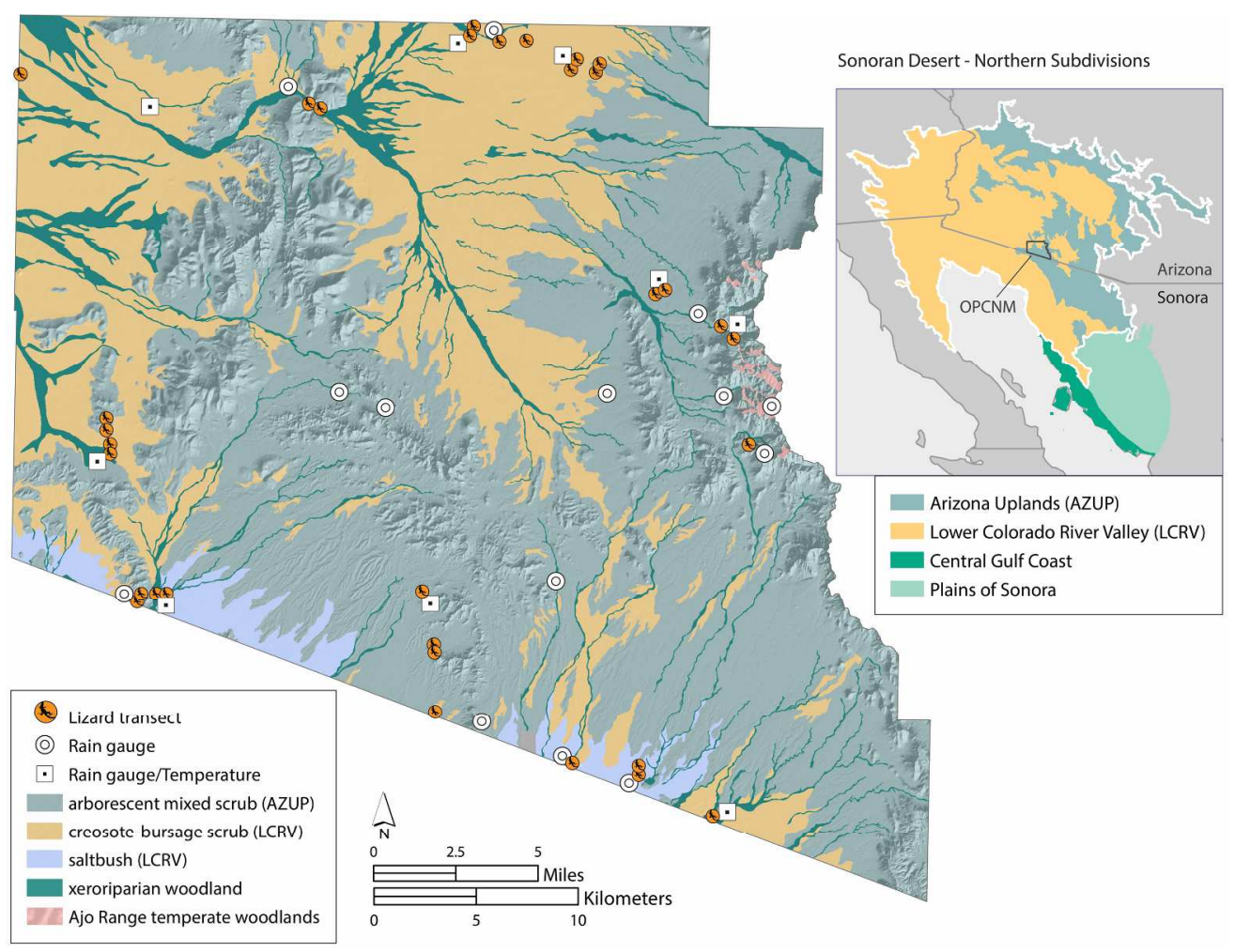

Fig. 1. Distribution of survey transects for lizards, weather stations, and vegetation communities in Organ Pipe Cactus National Monument (OPCNM). Inset map shows the distribution of four of the six subdivisions of the Sonoran Desert and the transitional nature of the study area.

$116 \times 88 \mathrm{~mm}(600 \times 600 \mathrm{DPI})$ 


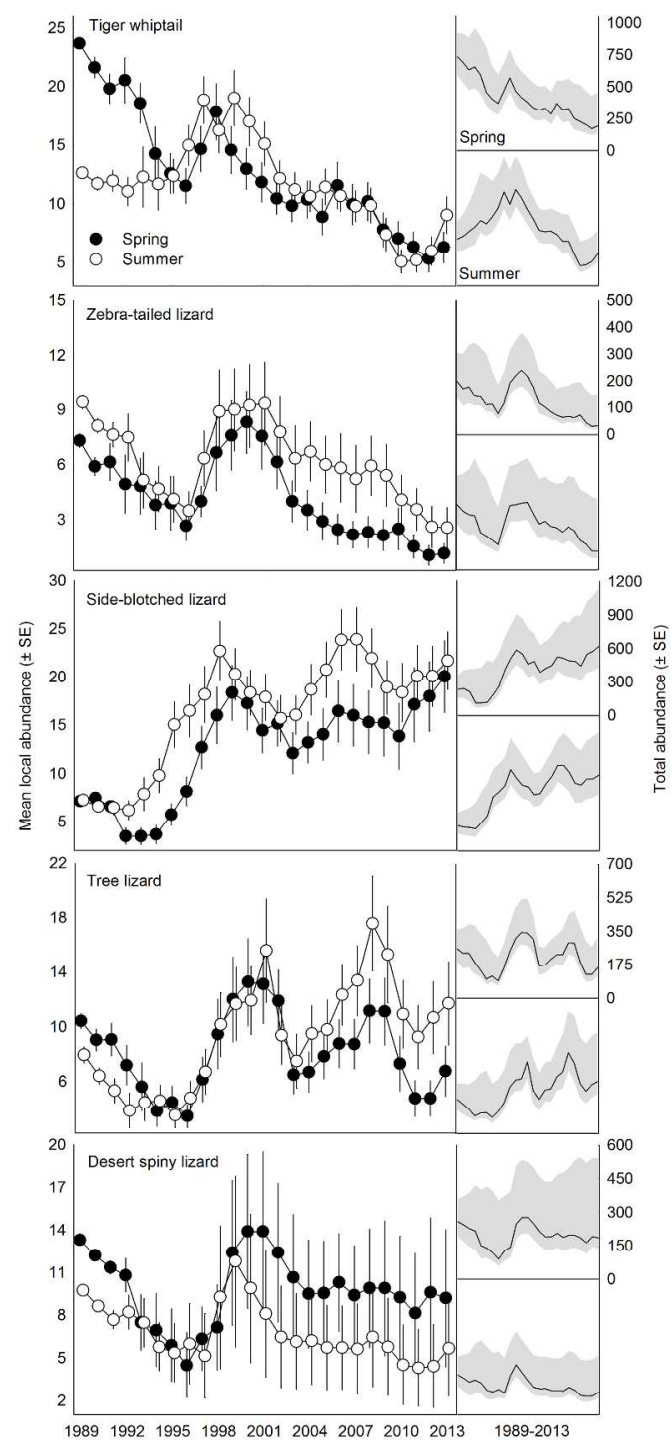

Fig. 2. Temporal variation in local and regional abundances of five species of lizards in spring and summer over 25 years in Organ Pipe Cactus National Monument (1989-2013). Estimates are from N-mixture models and are adjusted for variation in detection probability. 

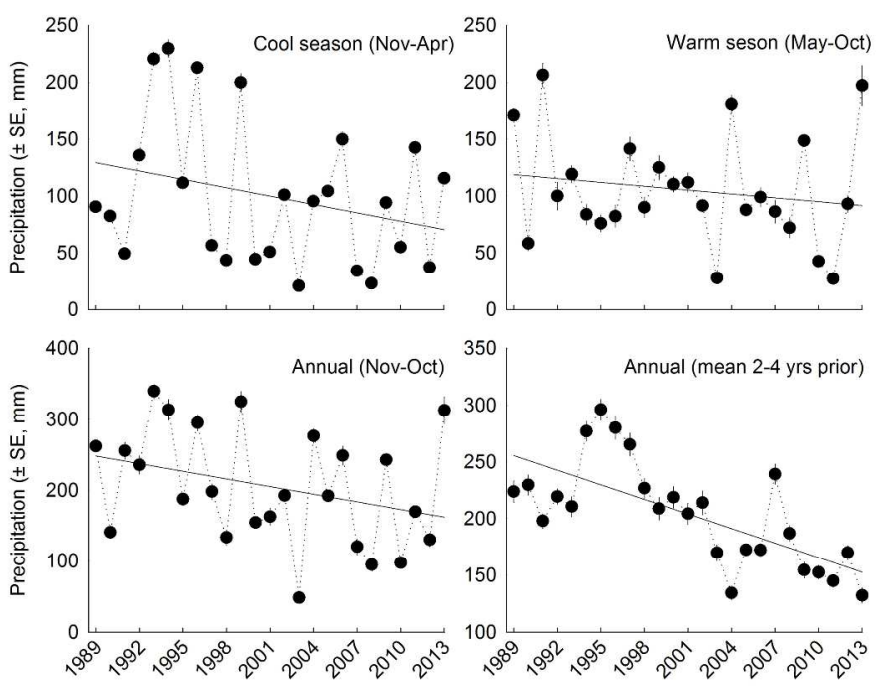

Fig. 3. Temporal variation in precipitation during four time periods considered when assessing the influence of climatic variation on lizard populations over 25 years in Organ Pipe Cactus National Monument (19892013). Estimates are from 17 weather stations located throughout the monument. Trend estimates are based on linear mixed effects models with autoregressive-moving-average structures to adjust for temporal autocorrelation. Parameter estimates and significance levels are summarized in Table 2.

$279 \times 360 \mathrm{~mm}(300 \times 300 \mathrm{DPI})$ 


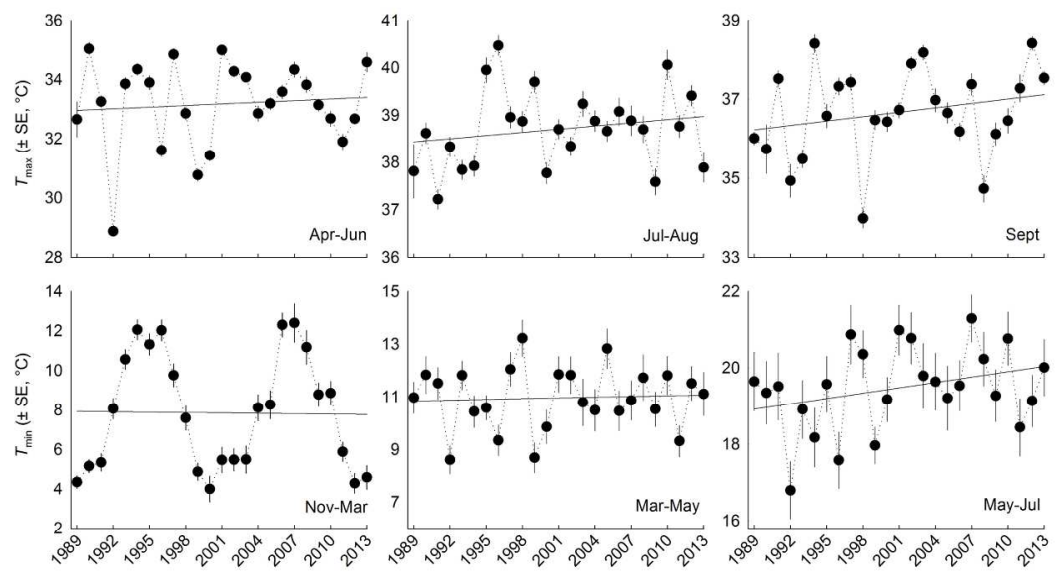

Fig. 4. Temporal variation in mean maximum (Tmax) and mean minimum (Tmin) daily temperature during various time periods considered when assessing the influence of climatic variation on lizard populations over 25 years in Organ Pipe Cactus National Monument (1989-2013). Estimates are from at 9 weather stations located throughout the monument. Trend estimates are based on linear mixed effects models with autoregressive-moving-average structures. Parameter estimates and significance levels are summarized in Table 2. 

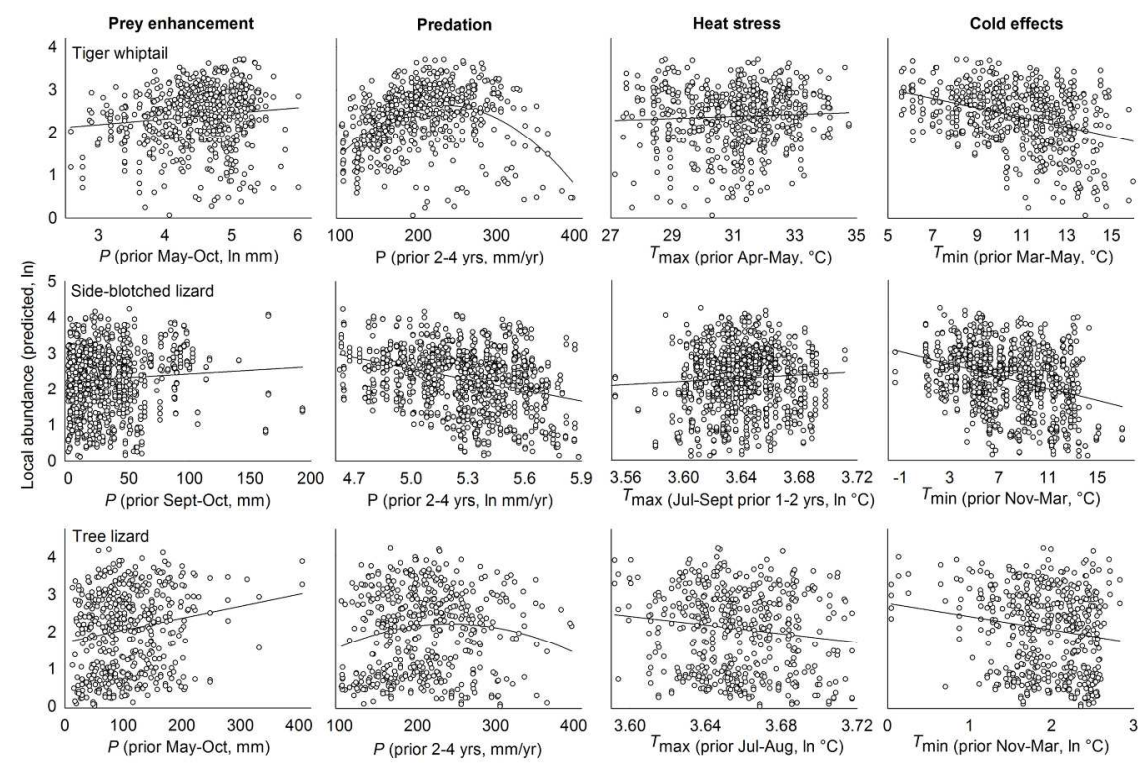

Fig. 5. Associations between lizard abundance and weather factors linked to four hypotheses that explained the influence of precipitation $(\mathrm{P}, \mathrm{mm})$ and temperature $\left(T,{ }^{\circ} \mathrm{C}\right)$ on spatiotemporal variation in lizard abundance in Organ Pipe Cactus National Monument over 25 years (1989-2013). Associations are shown for three species of lizards that exemplify differences in life history traits: the terrestrial, spring-summer breeding tiger whiptail; smaller, terrestrial, winter-spring breeding side-blotched lizard; and the arboreal ornate tree lizard. Regression lines are from linear mixed effects models with crossed random intercepts for transect and year, and are summarized in Table 4. 


\section{Supporting Information}

Appendix S1. Phenology of climatic effects on five focal species of lizards.

We synthesized the ecological literature and our field data on the five focal species of lizards in our analysis (Table S1) and used this information to develop hypotheses for the effects of climatic variation on abundances. In general, hypotheses are diagrammed in Fig. S1, and the resulting variables we employed as predicted effects are in Table S2. Here we provide details of the logic employed in representing each research hypothesis. All five species of lizards were represented similarly, but for one with divergent life history the application of climate variables was slightly modified as described below.

To avoid excessive complexity beyond established specifics and precision of knowledge of autecology and demographics (see Table S1), we treated the following four species identically:

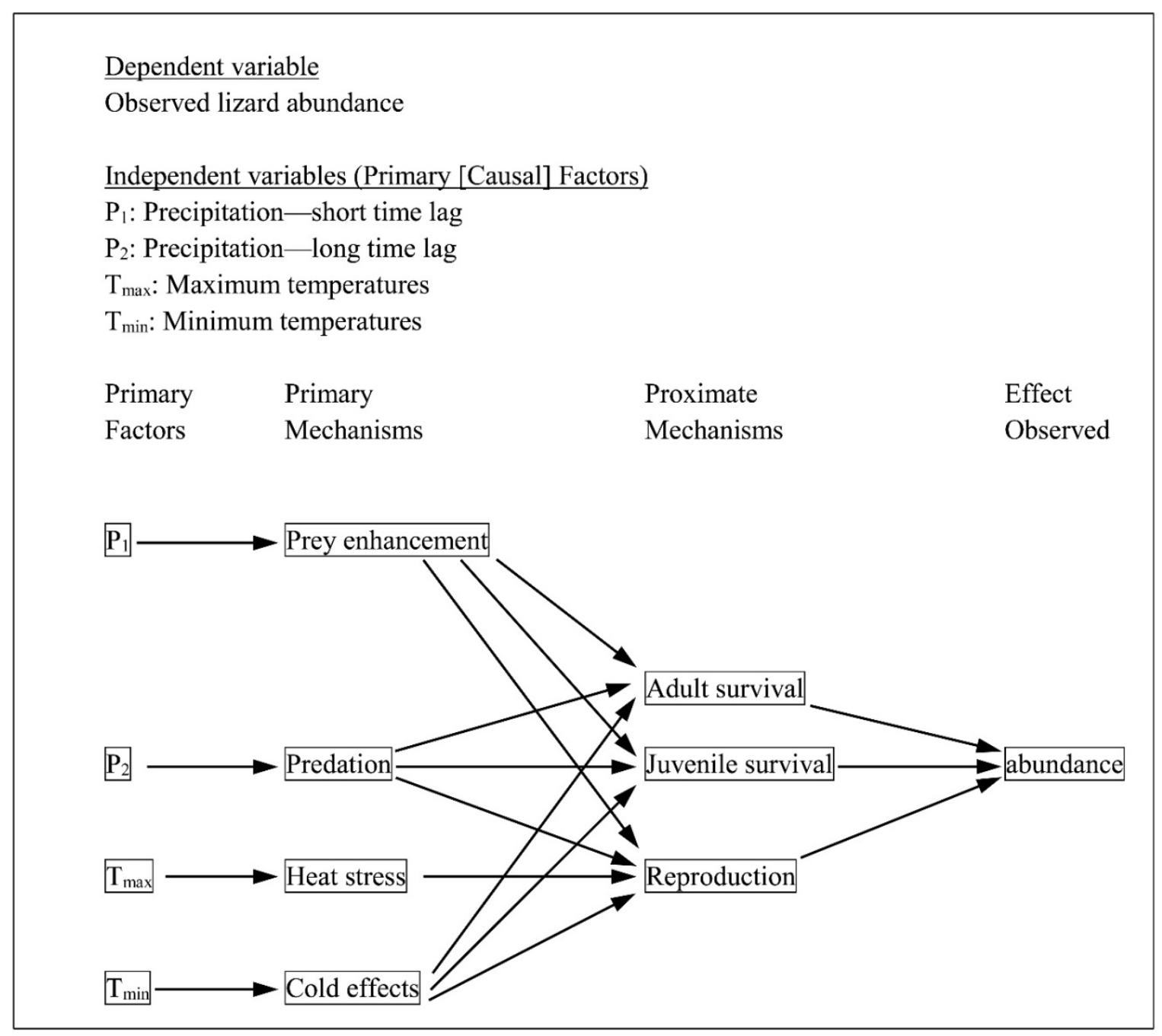

Figure S1. Diagrammatic representation of mechanistic connections of climate and weather variables to ecological hypotheses tested 
Table S1. Ecological characteristic for five focal species of lizards we considered in the Sonoran Desert. Items shown in parentheses are subsidiary aspects of niche or phenology.

\begin{tabular}{|c|c|c|c|c|c|}
\hline $\begin{array}{l}\text { English name } \\
\text { Scientific name }\end{array}$ & $\begin{array}{c}\text { Zebra-tailed lizard } \\
\text { Callisaurus } \\
\text { draconoides }\end{array}$ & $\begin{array}{c}\text { Desert spiny lizard } \\
\text { Sceloporus } \\
\text { magister }\end{array}$ & $\begin{array}{c}\text { Ornate tree lizard } \\
\text { Urosaurus } \\
\text { ornatus }\end{array}$ & $\begin{array}{c}\text { Side-blotched lizard } \\
\text { Uta } \\
\text { stansburiana }\end{array}$ & $\begin{array}{c}\text { Tiger whiptail } \\
\text { Aspidoscelis } \\
\text { tigris }\end{array}$ \\
\hline Family & Phrynosomatidae & Phrynosomatidae & Phrynosomatidae & Phrynosomatidae & Teiidae \\
\hline $\begin{array}{l}\text { Principal } \\
\text { macrohabitat }^{1}\end{array}$ & $\begin{array}{l}\text { flats, bajadas, } \\
\text { canyon bottoms }\end{array}$ & bajadas and flats & ubiquitous & ubiquitous & $\begin{array}{l}\text { bajadas, flats, } \\
\text { arid slopes }\end{array}$ \\
\hline $\begin{array}{l}\text { Lifestyle - } \\
\text { microhabitat }{ }^{1}\end{array}$ & terrestrial & $\begin{array}{c}\text { arboreal } \\
\text { (terrestrial) }\end{array}$ & $\begin{array}{c}\text { arboreal } \\
\text { (saxicolous) }\end{array}$ & $\begin{array}{l}\text { terrestrial, } \\
\text { saxicolous }\end{array}$ & terrestrial \\
\hline $\begin{array}{l}\text { Egg-laying } \\
\text { season }^{2}\end{array}$ & $\begin{array}{l}\text { (Apr) May-Aug } \\
\text { (Sept) }\end{array}$ & May-Aug & $\begin{array}{l}\text { (May) June-Aug } \\
\text { (Sept) }\end{array}$ & $\begin{array}{l}\text { Mar-May } \\
\text { (Jun-Aug) }\end{array}$ & $\begin{array}{l}\text { (Apr) May-Aug } \\
\text { (Sept) }\end{array}$ \\
\hline $\begin{array}{l}\text { } \text { Age }(\mathrm{YR}) \text { at } 1^{\text {st }} \\
\text { reproduction }{ }^{2}\end{array}$ & 1 & $1-1.5(2)$ & $(\approx 0.9) 1$ & $(\approx 0.7) 1$ & $1-1.5(2)$ \\
\hline$T_{\mathrm{b}}$ or $T_{\text {pref }}^{3}$ & 39.08 & 35.03 & 35.85 & 36.23 & 40.14 \\
\hline Clutch frequency ${ }^{4}$ & 2 & $1-2$ & $2-4$ & 3-6 & $2-3$ \\
\hline Mean clutch size ${ }^{4}$ & 4.6 & 7.8 & 6.9 & 4.2 & 2.6 \\
\hline Diet $^{4}$ & arthropods & $\begin{array}{c}\text { arthropods } \\
\text { (small lizards) }\end{array}$ & arthropods & arthropods & $\begin{array}{c}\text { arthropods } \\
\text { (small lizards) }\end{array}$ \\
\hline $\begin{array}{l}\text { Predominant } \\
\text { foraging behavior }\end{array}$ & sit-wait & sit-wait & sit-wait & sit-wait & active forager \\
\hline $\begin{array}{l}\text { General life } \\
\text { history type }\end{array}$ & $\begin{array}{l}\text { iteroparous, } \\
\text { multi-clutched }\end{array}$ & $\begin{array}{l}\text { iteroparous, } \\
\text { multi-clutched }\end{array}$ & $\begin{array}{c}\approx \text { annual, } \\
\text { multi-clutched }\end{array}$ & $\begin{array}{c}\text { annual, } \\
\text { multi-clutched }\end{array}$ & $\begin{array}{l}\text { iteroparous, } \\
\text { multi-clutched }\end{array}$ \\
\hline
\end{tabular}

\footnotetext{
${ }^{1}$ at $\mathrm{OPCNM},{ }^{2}$ from literature and unpublished OPCNM field data, ${ }^{3}$ estimated for OPCNM from literature, ${ }^{4}$ from literature
} 
The zebra-tailed lizard, desert spiny lizard, ornate tree lizard, and tiger whiptail all breed during the warm season (late April - early September), mature at $\approx 1-1.5$ years of age, and populations have approximately similar proportions of older adults and recruiting sub-adults from reproduction corresponding to predicted time-lagged effects of $\approx 1$ year. A fifth species, the common side-blotched lizard, breeds earlier (February-May, with limited breeding through August), matures earlier $\varangle(1$ year of age), and has nearly annual populatio $n$ turnover throughout its range. Thus it is expected to show different time-lag effects, especially between spring and summer seasons. Differences in climate-based ecological hypotheses linked to this species are described below.

We represented the prey enhancement hypothesis using precipitation variables at short time lags (Table S2). This hypothesis predicts increases in precipitation augment arthropod activity and primary productivity, which increases arthropod productivity and thus yields rapid increases in prey availability. Increased food resources are assumed to translate into increased reproductive output of lizards at time lags dependent on reproductive phenology and time to maturity. For the four similar species, summer rainfall leads to enhanced hatchling production, and based on our observations, many of these hatchlings are large enough to be counted the following spring and all are large enough by the following summer. The same logic applies to winter rainfall, as well as annual rainfall as defined in Table S2, thus indicating an approximately 1-year lag time relating precipitation to observed abundance changes in lizards. For fall precipitation, we assume that increased rainfall results primarily in increased juvenile growth and survival, and hence we also based our predictions on a 1-year lag time. The same applies to the positive effects of fall precipitation on adult survival, although we suspect this effect and other similar ones are likely small.

The predation hypothesis assumes the strongest effect of increased long-term precipitation ( $>1$ year time lag) results from increases in predator populations. These changes are caused by increased reproduction of predators in response to greater resource abundance, which results from bottom-up processes such as those identified by the prey enhancement hypothesis but at longer time lags. Although predator activity may also increase immediately (or at least at short time-lags, implying a <1-year time lag) in response to precipitation, we assumed this effect was small enough so that precipitation time lags linked to prey enhancement and predation variables could be separated. Although other factors such as intra- and interspecific competition may also operate at longer time lags in response to long-term precipitation, our predation hypothesis assumes these processes are weaker than predation. Further discussion of these issues is in the main text. We also considered 2-3-year time lags for precipitation linked to the predation hypotheses but this yielded somewhat weaker associations and is not presented in the results.

We represented high temperatures based on daily thermal maxima ( $T_{\max }$; Table S2). As with $T_{\min }$, we found no associations with abundances at short lag times that would suggest direct mortality from overheating as an important factor in lizard population change, and we therefore focused on likely effects of $T_{\max }$ on activity and thence reproductive output as described by Sinervo et al. (2010) and others. Sinervo et al. (2010) highlighted the potential importance of $T_{\max }$ during the breeding season on restricting activity and we therefore partitioned our examination of this factor into several variables representing effects of spring and summer breeding and of high temperatures just after the breeding season (late summer and fall) on reproductive output and 
resulting abundances in subsequent breeding seasons. Thus, we considered $T_{\max }$ at time lags of 1 and 2 years (Table S2).

We represented cold-effects hypotheses with four daily minimum temperature variables $\left(T_{\min }\right.$; Table S2). We assumed that high $T_{\min }$ increased resting metabolism, reducing stored energy and subsequent reproductive output, and following the logic for precipitation variables, operated at a 1-year time lag. We initially suspected that low winter temperatures might cause freeze mortality, resulting in a negative effect on populations at lag times of $<1$ year, but discarded this hypothesis after exploratory analys es indicated no associations. Thus it appears that overwinter freezing mortality is not important to lizard population changes in our system; nor did we find evidence that overwinter starvation of adults and larger juveniles was an important factor in population change, which would also have appeared as a <1-year time lagged effect. We tested for cold effects in other seasons following the same logic as above for winter thermal minima. We tested variables for minimum warm-season temperature effects in the pre-breeding and breeding periods (Table S2, $T_{\operatorname{mins}}$ and $T_{\operatorname{minBS}}$ ) to correspond with findings in the literature (Sinervo et al. 2010).

Slight modifications to time lags for various variables were needed to reflect the winter-spring breeding peak and high population turnover of the side-blotched lizard. These traits result in differences in reproductive output at different time lags for populations surveyed in summer versus spring. In summer, most observed individuals are subadults and small adults from the immediately preceding winter-spring breeding season (time-lag $=0$ for some variables) whereas in spring all observed individuals are adults, predominantly those from the previous winterspring plus a few older survivors (thus, time-lag $=1$ for most models). We thus lagged weather factors an additional time step when assessing associations with spring abundance. 
Table S2. Names and definitions of weather factors considered when assessing hypotheses for the effects of climatic variation on population dynamics of diurnal lizards in Organ Pipe Cactus National Monument over 25 years (1989-2013)..

\begin{tabular}{|c|c|c|c|c|}
\hline Factor & Code & Time Period & Definition & Hypotheses \\
\hline Precipitation & $P_{\mathrm{ws}}$ & Warm season & May through Oct of prior year & Prey enhancement \\
\hline Precipitation & $P_{\mathrm{cs}}$ & Cool season & Nov 2 years prior through April of prior year & Prey enhancement \\
\hline Precipitation & $P_{\text {fall }}$ & Fall & Sept and Oct of prior year & Prey enhancement \\
\hline Precipitation & $P_{\mathrm{yr}}$ & Annual & Sum of $P_{\mathrm{cs}}$ and $P_{\mathrm{ws}}$ & Prey enhancement \\
\hline Precipitation & $P_{\text {yr234 }}$ & Annual & Mean $P_{\text {yr }} 2-4$ years prior & Predation \\
\hline Temperature & $T_{\operatorname{minW}}$ & Cold season & 1-2 years prior Nov to $0-1$ year prior Mar & Cold effects \\
\hline Temperature & $T_{\min A}$ & Annual & $1-2$ years prior Nov to $0-1$ years prior Oct & Cold effects \\
\hline Temperature & $T_{\operatorname{minS}}$ & Emergence, pre-breeding, breeding season & 0-1 year prior Mar-May & Cold effects \\
\hline Temperature & $T_{\operatorname{minBS}}$ & Breeding season & 0-1 year prior May-Jul & Cold effects \\
\hline Temperature & $T_{\operatorname{maxSp}}$ & Spring & prior April-May & Heat stress \\
\hline Temperature & $T_{\operatorname{maxSp}}$ & Spring-early summer & prior April-June & Heat stress \\
\hline Temperature & $T_{\operatorname{maxSu}}$ & Summer & prior July-August & Heat stress \\
\hline Temperature & $T_{\operatorname{maxFall}}$ & Late summer & 2-yr prior Sept. & Heat stress \\
\hline Temperature & $T_{\operatorname{maxSpSu}}$ & Spring-summer & prior April-Sept & Heat stress \\
\hline Temperature & $T_{\text {maxSu-Sept }}$ & Mid-late summer & 2-yr prior July-Sept. & Heat stress \\
\hline
\end{tabular}




\section{References}

Asplund KK, Lowe CH (1964) Reproductive cycles of the iguanid lizards Urosaurus ornatus and Uta stansburiana in southeastern Arizona. Journal of Morphology 115, 27-33.

Ballinger RE (1977) Reproductive strategies: food availability as a source of proximal variation in a lizard. Ecology, 628-635.

Goldberg SR (2012) Reproduction of the yellow-backed spiny lizard, Sceloporus uniformis (Squamata: Phrynosomatidae) from California. Bulletin, Southern California Academy of Sciences, 111, 25-28.

Goldberg, SR (2013) Reproduction in the ornate tree lizard (Urosaurus ornatus), from Sonora, Mexico. Sonoran Herpetologist, 26, 47-51.

Goldberg SR, Lowe CH (1966) The reproductive cycle of the western whiptail lizard (Cnemidophorus tigris) in Southern Arizona. Journal of Morphology, 118, 543-548.

Hahn WE, Tinkle DW (1965) Fat body cycling and experimental evidence for its adaptive significance to ovarian follic le development in the lizard Uta stansburiana. Journal of Experimental Zoology, 158, 79-85.

M'closkey RT, Deslippe RJ, Szpak CP, Baia KA (1990) Ecological correlates of the variable mating system of an iguanid lizard. Oikos, 63-69.

M'closkey RT, Deslippe RJ, Szpak CP, Baia KA (1990) Tree lizard distribution and mating system: the influence of habitat and food resources. Canadian Journal of Zoology, 68, 2083-2089.

Michel L (1976) Reproduction in a southwest New Mexican population of Urosaurus ornatus. Southwestern Naturalist, 281-299.

Parker WS (1972) Ecological study of the western whiptail lizard, Cnemidophorus tigris gracilis, in Arizona. Herpetologica, 28, 360-369.

Parker WS, Pianka ER (1973) Notes on the ecology of the iguanid lizard, Sceloporus magister. Herpetologica, 143-152.

Parker WS, Pianka ER (1975) Comparative ecology of populations of the lizard Uta stansburiana. Copeia, 615-632.

Pianka ER (1986) Ecology and Natural History of Desert Lizards. Analyses of the Ecological Niche and Community Structure. Princeton University Press, Princeton, New Jersey.

Reilly SM, McBrayer LB, Miles DB, editors (2007) Lizard Ecology: The Evolutionary Consequences of Foraging Mode. Cambridge University Press, Cambridge, New York.

Rosen PC, Lowe CH (1996) Ecology of the amphibians and reptiles at Organ Pipe Cactus National Monument, Arizona. Cooperative Park Studies Unit, National Biological Service, University of Arizona, Tucson, Technical Report no. 53.

Sinervo B, Mendez-de-la-Cruz F, Miles DB, et al. (2010) Erosion of lizard diversity by climate change and altered thermal niches. Science, 328, 894-899. (Supplement).

Tanner WW, Krogh JE (1973) Ecology of Sceloporus magister at the Nevada test site, Nye County, Nevada. Great Basin Naturalist, 133-146.

Tanner WW, Krogh JE (1975) Ecology of the zebra-tailed lizard Callisaurus draconoides at the Nevada test site. Herpetologica, 302-316.

Tinkle DW (1976) Comparative data on the population ecology of the desert spiny lizard, Sceloporus magister. Herpetologica, 1-6.

Turner FB, Medica PA, Lannom Jr JR, Hoddenbach GA (1969) A demographic analys is of fenced populations of the whiptail lizard, Cnemidophorus tigris, in southern Nevada. Southwestern Naturalist, 189-201. 
Tinkle DW (1967) The life and demography of the side-blotched lizard, Uta stansburiana. Miscellaneous Publications (University of Michigan Museum of Zoology), 132, 1-182.

Tinkle DW, Dunham AE (1983) Demography of the tree lizard, Urosaurus ornatus, in central Arizona. Copeia, 585-598.

Van Loben Sels RC, Vitt LJ (1984) Desert lizard reproduction: seasonal and annual variation in Urosaurus ornatus (Iguanidae). Canadian Journal of Zoology, 62, 1779-1787.

Vitt LJ, Ohmart RD (1974) Reproduction and ecology of a Colorado River population of Sceloporus magister (Sauria: Iguanidae). Herpetologica, 410-417.

Vitt LJ, Ohmart RD (1977) Ecology and reproduction of lower Colorado River lizards: I. Callisaurus draconoides (Iguanidae). Herpetologica, 214-222.

Vitt LJ, Ohmart RD (1977) Ecology and reproduction of Lower Colorado River lizards: II. Cnemidophorus tigris (Teiidae), with comparisons. Herpetologica, 223-234.

Vitt LJ, Van Loben Sels RC, Ohmart RD (1981) Ecological relationships among arboreal desert lizards. Ecology, 62, 398-410. 
Appendix S2. Correlations among climatic attributes linked to our four hypotheses.

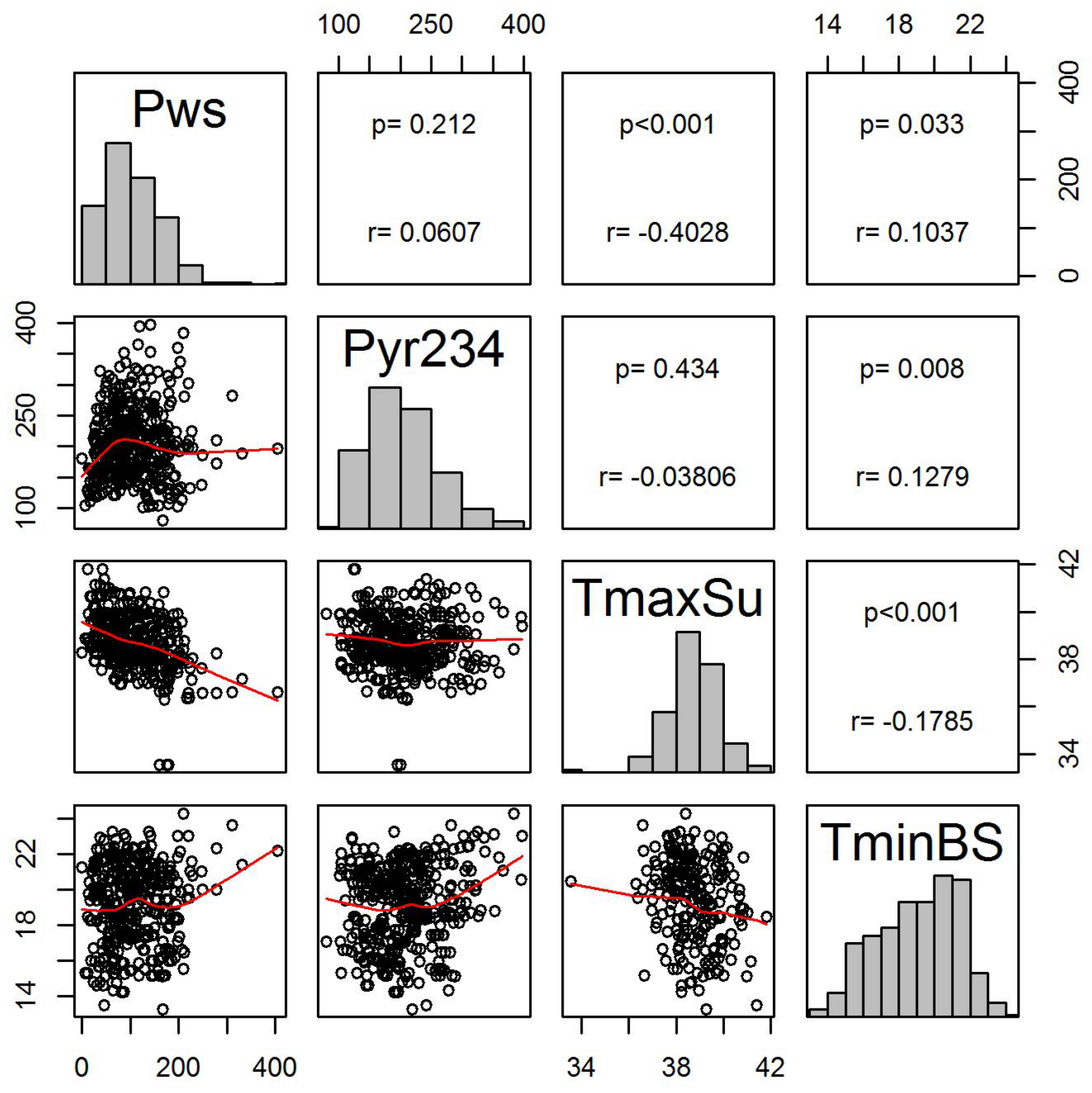

Figure S2A. Correlations between warm-season climatic attributes linked to each of our four hypotheses. Names and definitions of factors are in Table S2. 


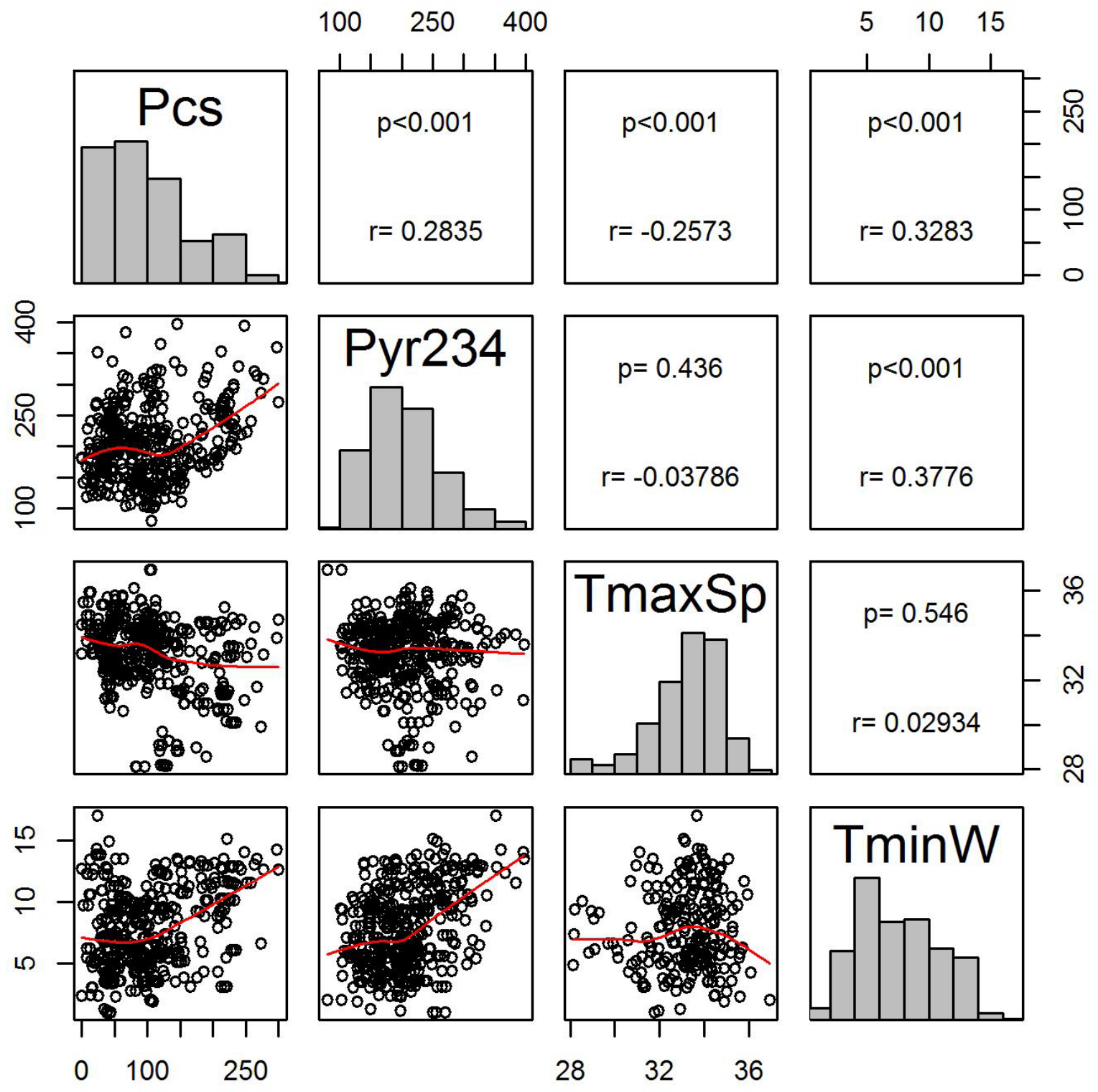

Figure S2B. Correlations between cool-season climatic attributes linked to each of our four hypotheses. Names and definitions of factors are in Table S2. 


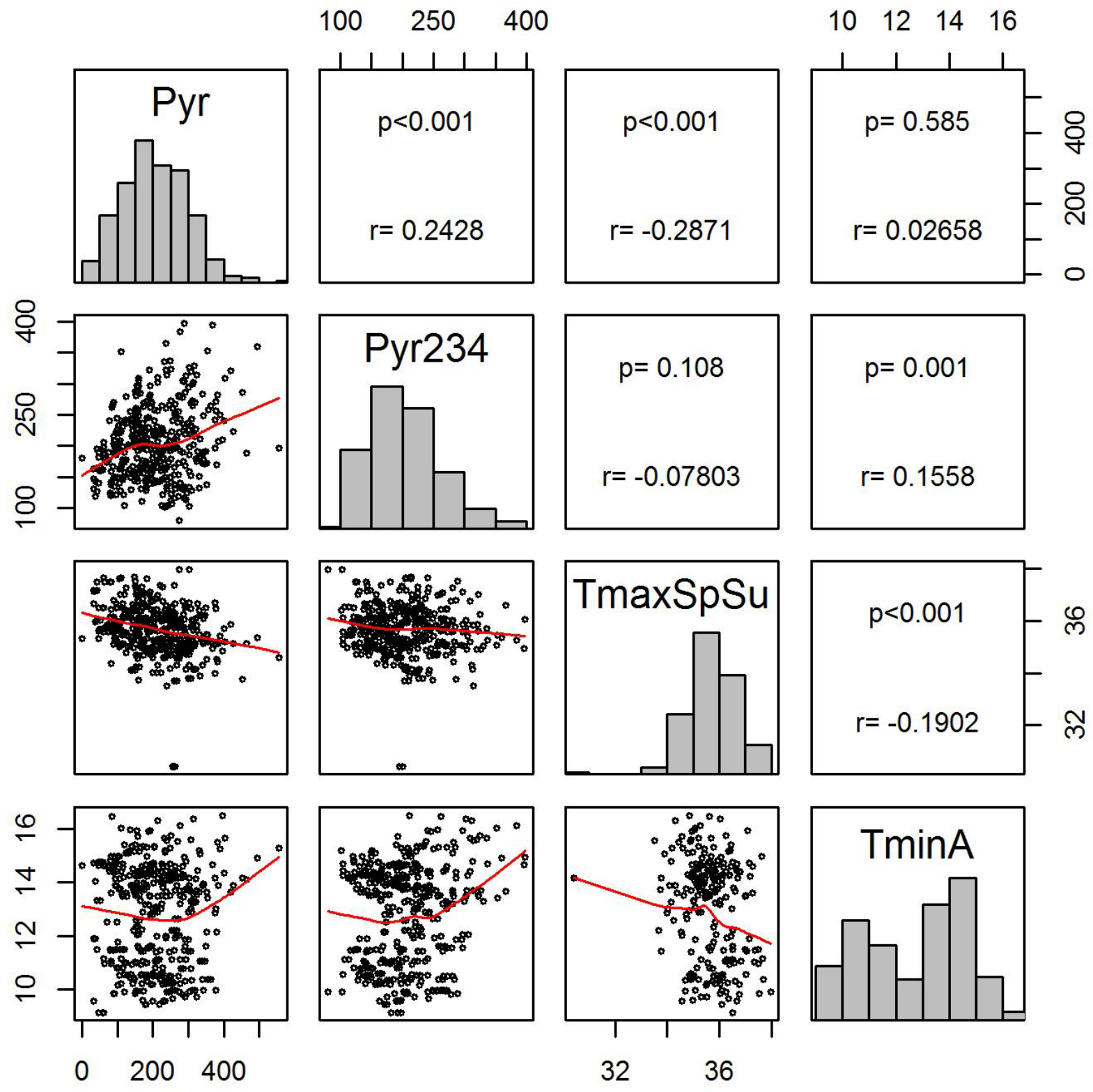

Figure S2C. Correlations between annual climatic attributes linked to each of four hypotheses. Names and definitions of factors are in Table S2. 
Table S3. Binomial detection models for five species of lizards in Organ Pipe Cactus National Monument over 25 years (1989-2013). Each species was surveyed along line transects 3-8 times per day in both spring and summer of each year at up to 32 sites per year. Count data from these repeated daily surveys were modeled with hierarchical $N$-mixture models that explicitly considered variation in detection probability.

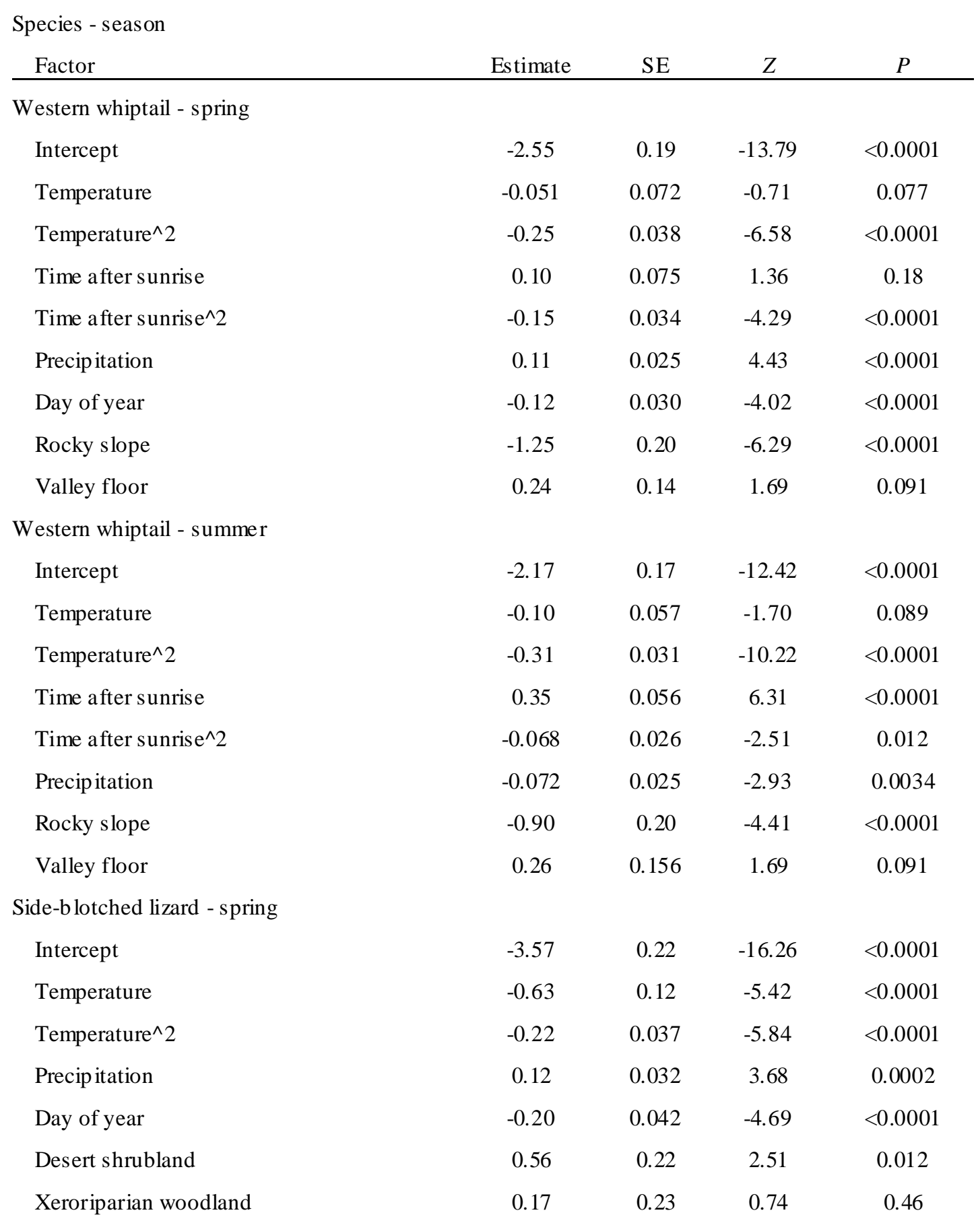


Soil fine

Side-b lotched lizard - summer

Intercept

Temperature

Temperature $\wedge 2$

Time after sunrise

Time after sunrise $\mathrm{e}^{\wedge} 2$

Day of year

Day of year^2

Soil fine

Zebra-tailed lizard - spring

Intercept

Temperature

Temperature $\wedge 2$

Precip itation

Rocky slope

Valley floor

Desert shrubland

Xeroriparian woodland

Zebra-tailed lizard - summer

Intercept

Temperature

Temperature $\wedge 2$

Day of year

Rocky slope

Valley floor

Tree lizard - spring

Intercept
Temperature
Temperature^$^{\wedge} 2$
Time after sunrise
Time after sunrise^ 2
Precip itation
Desert shrubland
Xeroriparian woodland

Tree lizard - summer $\begin{array}{llll}-0.52 & 0.18 & -2.89 & 0.0039\end{array}$

$\begin{array}{llll}-2.41 & 0.15 & -16.26 & <0.0001\end{array}$

$\begin{array}{llll}-0.52 & 0.070 & -7.44 & <0.0001\end{array}$

$\begin{array}{llll}-0.33 & 0.035 & -9.48 & <0.0001\end{array}$

$\begin{array}{llll}-0.32 & 0.075 & -4.32 & <0.0001\end{array}$

$\begin{array}{llll}0.072 & 0.035 & 2.01 & 0.045\end{array}$

$\begin{array}{llll}0.026 & 0.049 & 0.54 & 0.59\end{array}$

$\begin{array}{llll}-0.18 & 0.034 & -5.37 & <0.0001\end{array}$

$\begin{array}{llll}-0.48 & 0.15 & -3.21 & 0.0013\end{array}$

$\begin{array}{llll}-2.35 & 0.22 & -10.48 & <0.0001\end{array}$

$\begin{array}{llll}0.71 & 0.057 & 12.40 & <0.0001\end{array}$

$\begin{array}{llll}-0.64 & 0.059 & -10.71 & <0.0001\end{array}$

$\begin{array}{llll}0.23 & 0.047 & 4.95 & <0.0001\end{array}$

$\begin{array}{llll}-1.30 & 0.30 & -4.30 & <0.0001\end{array}$

$\begin{array}{llll}-0.77 & 0.30 & -2.57 & 0.010\end{array}$

$\begin{array}{llll}-0.53 & 0.39 & -1.38 & 0.17\end{array}$

$\begin{array}{llll}0.82 & 0.30 & 2.72 & 0.0066\end{array}$

$\begin{array}{llll}-2.68 & 0.18 & -14.72 & <0.0001\end{array}$

$\begin{array}{llll}0.36 & 0.054 & 6.77 & <0.0001\end{array}$

$\begin{array}{llll}-0.42 & 0.054 & -7.72 & <0.0001\end{array}$

$\begin{array}{llll}-0.17 & 0.058 & -2.87 & 0.0041\end{array}$

$\begin{array}{llll}-1.15 & 0.37 & -3.10 & 0.0020\end{array}$

$\begin{array}{llll}-0.30 & 0.19 & -1.54 & 0.12\end{array}$

$\begin{array}{llll}-3.12 & 0.20 & -15.46 & <0.0001\end{array}$

$\begin{array}{llll}-0.29 & 0.050 & -5.94 & <0.0001\end{array}$

$\begin{array}{llll}-0.068 & 0.021 & -3.28 & 0.0011\end{array}$

$\begin{array}{llll}-0.34 & 0.046 & -7.25 & <0.0001\end{array}$

$\begin{array}{llll}-0.13 & 0.030 & -4.50 & <0.0001\end{array}$

$\begin{array}{llll}0.13 & 0.026 & 4.88 & <0.0001\end{array}$

$\begin{array}{llll}-0.022 & 0.26 & -0.08 & 0.93\end{array}$

$\begin{array}{llll}0.83 & 0.20 & 4.09 & <0.0001\end{array}$ 


\begin{tabular}{lcccc} 
Intercept & -3.18 & 0.23 & -14.11 & $<0.0001$ \\
Temperature & -0.76 & 0.071 & -10.64 & $<0.0001$ \\
Temperature^2 & -0.11 & 0.026 & -4.43 & $<0.0001$ \\
Time after sunrise & 0.033 & 0.058 & 0.57 & 0.57 \\
Time after sunrise ${ }^{\wedge 2}$ & -0.12 & 0.033 & -3.66 & 0.0003 \\
Day of year & -0.38 & 0.052 & -7.38 & $<0.0001$ \\
Day of year^2 & 0.11 & 0.039 & 2.97 & 0.0030 \\
Rocky slope & 1.36 & 0.31 & 4.45 & $<0.0001$ \\
Valley floor & -0.074 & 0.23 & -0.32 & 0.75 \\
Desert spiny lizard - spring & & & & \\
Intercept & -6.06 & 0.41 & -14.81 & $<0.0001$ \\
Time after sunrise & -0.42 & 0.096 & -4.40 & $<0.0001$ \\
Time after sunris $\mathrm{A}^{\wedge} 2$ & -0.23 & 0.094 & -2.42 & 0.016 \\
Soil fine & 1.47 & 0.39 & 3.81 & 0.0001 \\
Desert spiny lizard - summer & & & & \\
Intercept & -5.69 & 0.42 & -13.50 & $<0.0001$ \\
Time after sunrise & -0.32 & 0.075 & -4.25 & $<0.0001$ \\
Soil fine & 1.35 & 0.40 & 3.37 & 0.0008 \\
\hline
\end{tabular}



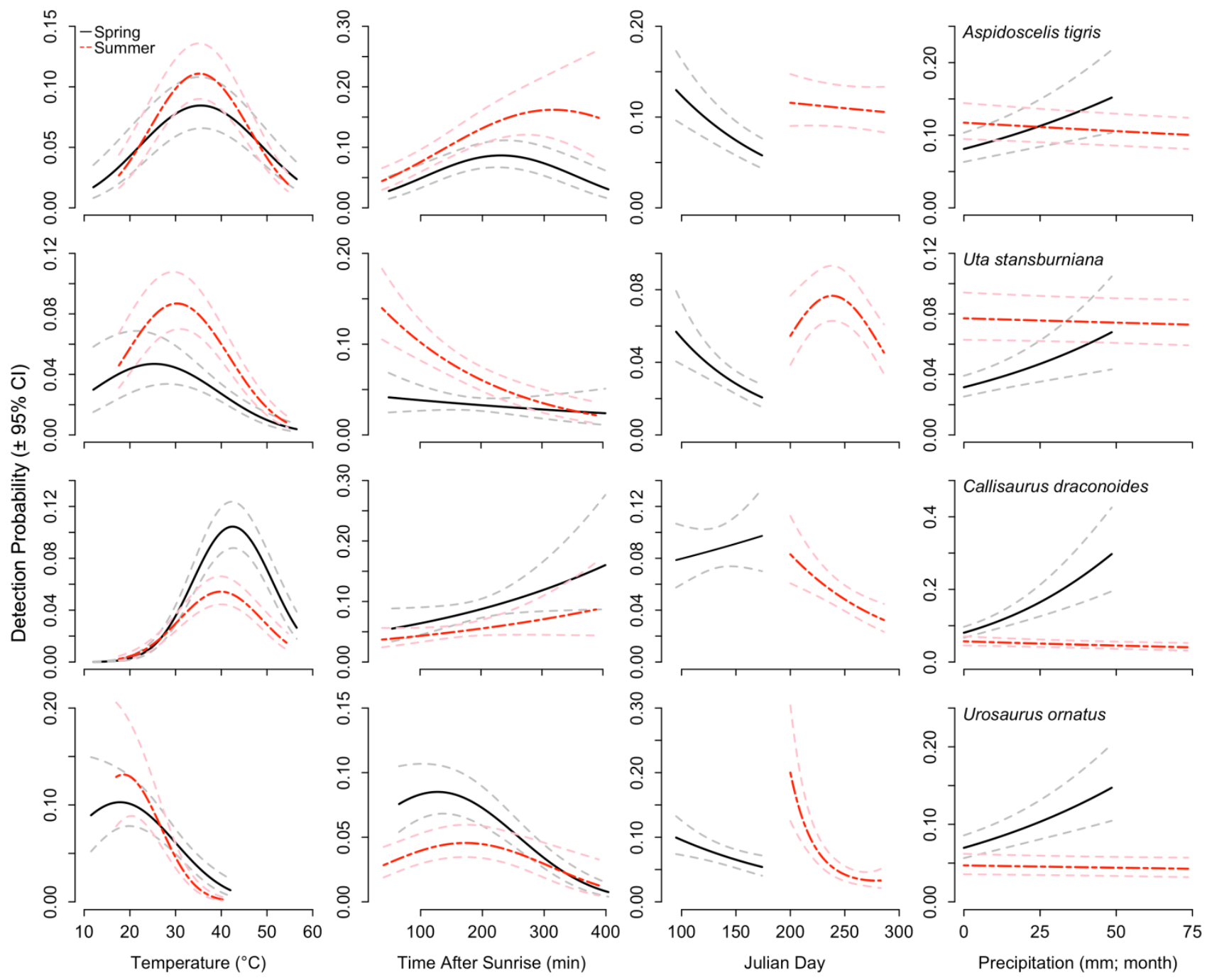

Figure S3. Effects of temperature, precipitation, and temporal factors on detection probability of four species of lizards in Organ Pipe Cactus National Monument, 1989-2013. Estimates are from binomial detection models summarized in Table S3 

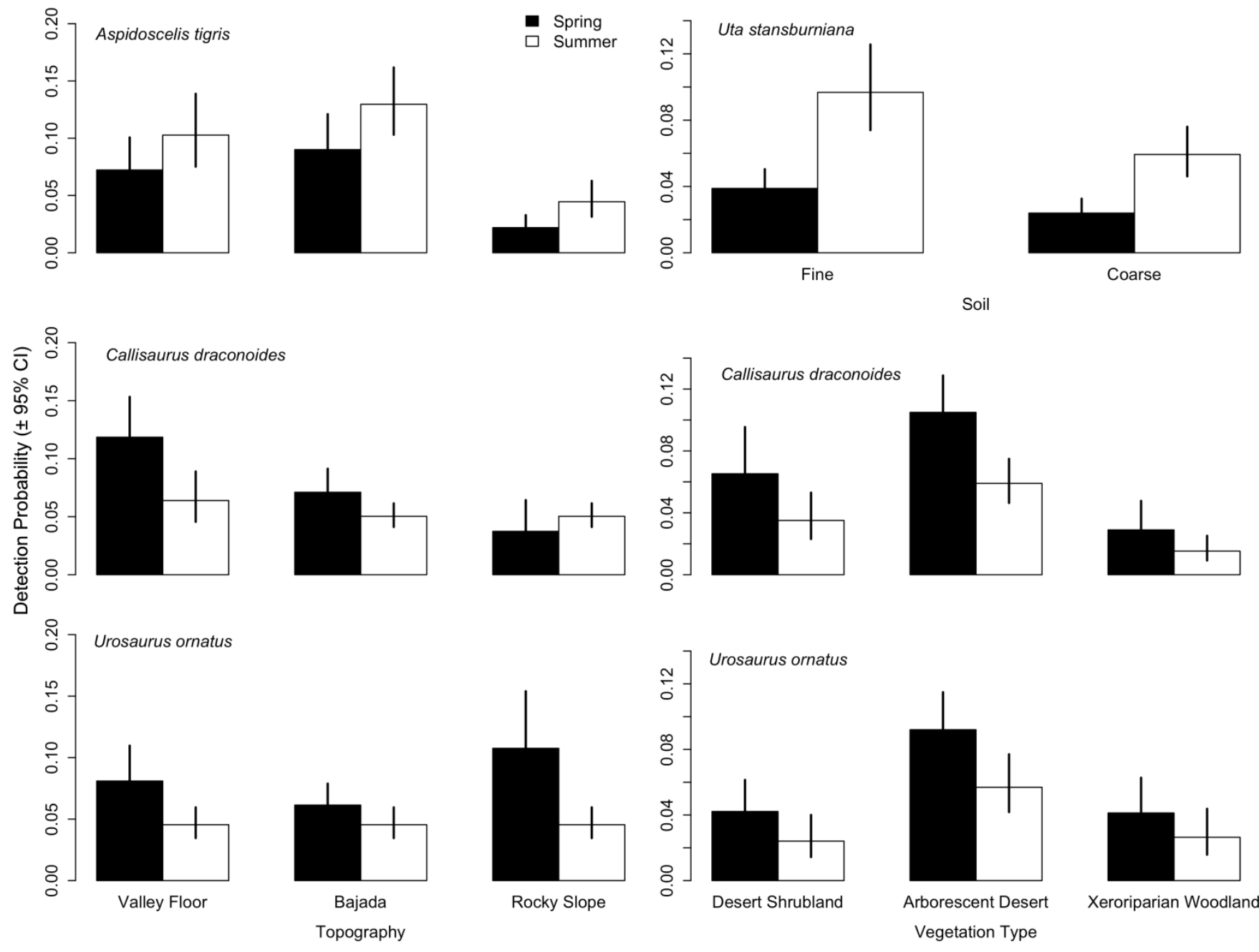

Figure S4. Effects of categorical covariates on detection probability of four species of diurnal lizards in Organ Pipe Cactus National Monument, 1989-2013. Estimates are from binomial detection models summarized in Table S3. 
Table S4. Rankings of hypothesized models that explained the influence of local weather on spatiotemporal variation in abundance (ln no.) of five species of diurnal lizards in Organ Pipe Cactus National Monument over a 25-year period (1989-2013). $K$ represents the number of model parameters, $\Delta \mathrm{AIC}_{\mathrm{c}}$ is the change in AIC between each model and the best approximating model, and AIC $_{\mathrm{c}}$ weights $\left(w_{i}\right)$ are probabilities each model is the best approximating model in each model set. Variables representing each hypothes is are in Table 4.

\begin{tabular}{|c|c|c|c|}
\hline Hypothes is & $K$ & $\triangle \mathrm{AICc}$ & $w_{i}$ \\
\hline \multicolumn{4}{|l|}{ Western whiptail } \\
\hline Prey + predation + warm stress + cold effects & 9 & 0.00 & 1.000 \\
\hline Prey + predation + cold effects & 8 & 4.23 & 0.120 \\
\hline Predation + warm stress + cold effects & 8 & 4.57 & 0.100 \\
\hline Predation + cold effects & 7 & 8.09 & 0.020 \\
\hline Prey + predation + warm stress & 8 & 9.93 & 0.010 \\
\hline Prey + predation & 7 & 11.67 & 0.000 \\
\hline Prey + warm stress + cold effects & 7 & 12.96 & 0.000 \\
\hline Prey + cold effects & 6 & 17.66 & 0.000 \\
\hline Predation & 6 & 17.99 & 0.000 \\
\hline Cold effects + warm stress & 6 & 19.76 & 0.000 \\
\hline Prey + warm stress & 6 & 22.06 & 0.000 \\
\hline Cold effects & 5 & 23.99 & 0.000 \\
\hline Prey & 5 & 25.72 & 0.000 \\
\hline Warm stress & 5 & 31.00 & 0.000 \\
\hline Null & 4 & 34.37 & 0.000 \\
\hline \multicolumn{4}{|l|}{ Side-bl otched lizard } \\
\hline Prey + predation + warm stress + cold effects & 8 & 0.00 & 1.000 \\
\hline Predation + warm stress + cold effects & 7 & 1.59 & 0.451 \\
\hline Prey + predation + cold effects & 7 & 4.31 & 0.116 \\
\hline Predation + cold effects & 6 & 5.91 & 0.052 \\
\hline Prey + warm stress + cold effects & 7 & 6.07 & 0.048 \\
\hline Prey + predation + warm stress & 7 & 7.88 & 0.019 \\
\hline Cold effects + warm stress & 6 & 8.01 & 0.018 \\
\hline
\end{tabular}




\begin{tabular}{|c|c|c|c|}
\hline Prey + cold effects & 6 & 9.59 & 0.008 \\
\hline Cold effects & 5 & 11.48 & 0.003 \\
\hline Prey + predation & 6 & 12.60 & 0.002 \\
\hline Predation & 5 & 15.10 & 0.001 \\
\hline Prey + warm stress & 6 & 16.02 & 0.000 \\
\hline Warm stress & 5 & 18.86 & 0.000 \\
\hline Prey & 5 & 19.67 & 0.000 \\
\hline Null & 4 & 22.44 & 0.000 \\
\hline \multicolumn{4}{|l|}{ Zebra-tailed lizard } \\
\hline Prey + warm stress + cold effects & 8 & 0.00 & 1.000 \\
\hline Prey + cold effects & 7 & 1.84 & 0.399 \\
\hline Cold effects + warm stress & 7 & 3.40 & 0.183 \\
\hline Prey + predation + warm stress + cold effects & 10 & 3.68 & 0.159 \\
\hline Cold effects & 6 & 5.22 & 0.073 \\
\hline Prey + predation + cold effects & 9 & 5.70 & 0.058 \\
\hline Predation + warm stress + cold effects & 9 & 7.06 & 0.029 \\
\hline Predation + cold effects & 8 & 9.00 & 0.011 \\
\hline Prey + warm stress & 6 & 10.38 & 0.006 \\
\hline Warm stress & 5 & 12.67 & 0.002 \\
\hline Prey + predation + warm stress & 8 & 13.13 & 0.001 \\
\hline Prey & 5 & 14.45 & 0.001 \\
\hline Null & 4 & 16.71 & 0.000 \\
\hline Prey + predation & 7 & 17.66 & 0.000 \\
\hline Predation & 6 & 20.13 & 0.000 \\
\hline \multicolumn{4}{|l|}{ Tree lizard } \\
\hline Prey + predation + warm stress + cold effects & 9 & 0.00 & 1.000 \\
\hline Predation + warm stress + cold effects & 8 & 2.41 & 0.299 \\
\hline Prey + predation + warm stress & 8 & 5.22 & 0.074 \\
\hline Prey + predation + cold effects & 8 & 8.72 & 0.013 \\
\hline Predation + cold effects & 7 & 13.18 & 0.001 \\
\hline Prey + predation & 7 & 15.26 & 0.000 \\
\hline Predation & 6 & 22.09 & 0.000 \\
\hline Prey + warm stress + cold effects & 7 & 22.67 & 0.000 \\
\hline Cold effects + warm stress & 6 & 23.88 & 0.000 \\
\hline Prey + warm stress & 6 & 25.95 & 0.000 \\
\hline Warm stress & 5 & 28.47 & 0.000 \\
\hline Prey + cold effects & 6 & 34.53 & 0.000 \\
\hline
\end{tabular}


Cold effects

Prey

Null

Desert spiny lizard

Prey + warm stress + cold effects

Cold effects + warm stress

Prey + predation + warm stress + cold effects

Predation + warm stress + cold effects

Cold effects

Prey + cold effects

Predation + cold effects

Prey + predation + cold effects

Prey + warm stress

Prey + predation + warm stress

Warm stress

Predation

Null

Prey + predation

Prey
$5 \quad 38.24 \quad 0.000$

$5 \quad 39.25 \quad 0.000$

$4 \quad 45.14 \quad 0.000$

$8 \quad 0.00 \quad 1.000$

$\begin{array}{lll}7 & 1.09 & 0.579\end{array}$

$9 \quad 1.54 \quad 0.463$

$\begin{array}{lll}8 & 2.21 & 0.332\end{array}$

$\begin{array}{lll}6 & 2.87 & 0.238\end{array}$

$\begin{array}{lll}7 & 3.07 & 0.216\end{array}$

$\begin{array}{lll}7 & 3.60 & 0.165\end{array}$

$\begin{array}{lll}8 & 4.18 & 0.124\end{array}$

$\begin{array}{lll}6 & 7.57 & 0.023\end{array}$

$\begin{array}{lll}7 & 8.22 & 0.016\end{array}$

$5 \quad 8.43 \quad 0.015$

$\begin{array}{lll}5 & 8.97 & 0.011\end{array}$

$\begin{array}{lll}4 & 9.81 & 0.007\end{array}$

$\begin{array}{lll}6 & 9.91 & 0.007\end{array}$

\begin{tabular}{lll}
5 & 9.98 & 0.007 \\
\hline
\end{tabular} 